\title{
Electrical, Mechanical and Chemical Behavior of $\mathrm{Li}_{1.2} \mathrm{Zr}_{1.9} \mathrm{Sr}_{0.1}\left(\mathrm{PO}_{4}\right)_{3}$
}

\author{
Sheila Smith ${ }^{1}$, Travis Thompson ${ }^{1}$, Jeff Sakamoto ${ }^{1}$, \\ Jan L. Allen ${ }^{2}$ and Jeff Wolfenstine ${ }^{2}$ \\ ${ }^{1}$ Department of Mechanical Engineering \\ University of Michigan \\ Ann Arbor, MI 48109 \\ ${ }^{2}$ Army Research Laboratory \\ RDRL-SED-C \\ 2800 Powder Mill Road \\ Adelphi, MD 20783
}

\begin{abstract}
The elastic modulus, fracture toughness, ionic conductivity, thermal expansion, Li and water stability of dense $(\sim 97 \%)$ fine-grain $(\sim 10 \mu \mathrm{m}) \mathrm{Li}_{1.2} \mathrm{Zr}_{1.9} \mathrm{Sr}_{0.1}\left(\mathrm{PO}_{4}\right)_{3}$ (LZSP)consolidated by reactive hot-pressing was investigated. Low values of elastic modulus (25.2 and $40.9 \mathrm{GPa}$ ), fracture toughness $\left(0.29\right.$ and $\left.0.37 \mathrm{MPa}-\mathrm{m}^{1 / 2}\right)$, total conductivity $\left(2.1 \times 10^{-5} \mathrm{~S} / \mathrm{cm}\right)$ and thermal expansion hysteresis were exhibited as result of the presence of microcracks formed during cooling from the hot-pressing temperature. The lattice conductivity of LZSP is $0.85 \times 10^{-4} \mathrm{~S} / \mathrm{cm}$ with an activation energy for bulk conductivity of $0.29 \mathrm{eV}$. The results of $\mathrm{Li} / \mathrm{LZSP} / \mathrm{Li}$ cell impedance as a function of time and surface examination suggest that LZSP is not stable against metallic lithium. The results of the water stability test suggest that LZSP is a possible membrane for use in aqueous Li-Air cells. The results of this study reveal for the case of lithium zirconium phosphates are as follows: 1] a small grain size is required to prevent microcracking to avoid a reduction in total conductivity and mechanical properties and 2] even though they do not contain a transition metal cation they are not stable against $\mathrm{Li}$ at room temperature.
\end{abstract}




\section{Introduction}

There has been renewed interest in solid-state batteries composed of a Li anode, Li-ion conductingsolidelectrolyte and high voltage cathode, as a result of their potential to lead to higher energy density and safer batteries than the currentLi-ion batteries [1-3]. For a solid electrolyte to be used in this configuration it must meet certain criteria, these include: 1) high ionic conductivity, 2) negligibleelectronicconductivity,3) chemicalstability with the Li anode and potential cathode materialsand 4) adequate mechanical properties (e.g., elastic modulus) [4-6]. Recently, several NaSICON framework materials with the rhombohedral $\mathrm{R} \overline{3} \mathrm{c}$ space group containing no transition metal cations have been investigated as possible electrolytes for use in an all solid-state battery with a $\mathrm{Li}$ anode. The ionic conductivity of $\mathrm{Li}_{1.2} \mathrm{Zr}_{1.9} \mathrm{Ca}_{0.1}\left(\mathrm{PO}_{4}\right)_{3}[7,8]$, $\mathrm{Li}_{1.2} \mathrm{Zr}_{1.9} \mathrm{Sr}_{0.1}\left(\mathrm{PO}_{4}\right)_{3}$ [9] and $\mathrm{Li}_{1.15} \mathrm{Y}_{0.15} \mathrm{Zr}_{1.85}\left(\mathrm{PO}_{4}\right)_{3}[10]$, has been measured with total conductivities of;4.9 $\times 10^{-5}, 3.4 \times 10^{-5}$ and $1.4 \times 10^{-4} \mathrm{~S} / \mathrm{cm}$,respectively. Only theelectronic conductivity of $\mathrm{Li}_{1.2} \mathrm{Zr}_{1.9} \mathrm{Sr}_{0.1}\left(\mathrm{PO}_{4}\right)_{3}$ [9] has been reported. Itwas suggested [10] since, they contain no transition metal cations, that they would be stable with metallic Li at room temperature however, no evidenceof this stability was shown. In addition, the mechanical properties of these materials has not been reported. Furthermore, it is known that microcracking can occur in rhombohedral phase materials during cooling from high temperature(where densification occurs) to room temperature if the grain size is above a critical grain size [11,12]. This occurs as a result of the difference in thermal expansion coefficients between the a and c crystallographic directions in the rhombohedral phase. If microcracking occurs a decrease in ionic conductivity andmechanical properties will occur [13-16]. There is no mention of microcracking in the $\mathrm{Li}_{1.2} \mathrm{Zr}_{1.9} \mathrm{Ca}_{0.1}\left(\mathrm{PO}_{4}\right)_{3}, \mathrm{Li}_{1.2} \mathrm{Zr}_{1.9} \mathrm{Sr}_{0.1}\left(\mathrm{PO}_{4}\right)_{3}$ and $\mathrm{Li}_{1.15} \mathrm{Y}_{0.15} \mathrm{Zr}_{1.85}\left(\mathrm{PO}_{4}\right)_{3}$ materials 
however,from published micrographsit appears that microcrackingmay haveoccurred in these materials [8-10].

This study aims to provide absent information on NaSICON framework materials which contain no transition metal cations and are potential electrolytes in all solid-state batteries with a $\mathrm{Li}$ anode.It is the goal of this study to investigate not only the ionic and electronic conductivity, but also thethermal expansion coefficient, elastic modulus, hardness, fracture toughness, chemical stability with $\mathrm{Li}$ and water stabilityof dense $\mathrm{Li}_{1.2} \mathrm{Zr}_{1.9} \mathrm{Sr}_{0.1}\left(\mathrm{PO}_{4}\right)_{3}(\mathrm{LZSP})$. This composition was chosen for the following reasons: 1) contains no transition metal cations thus, it should be stable with metallic Li and 2)it has been shownin the zirconium phosphate system that the larger size Sr cation compared to the Ca cation lead to reduced microcracking[13]. Furthermore, in the recent study on $\mathrm{Li}_{1.2} \mathrm{Zr}_{1.9} \mathrm{Sr}_{0.1}\left(\mathrm{PO}_{4}\right)_{3}$ the contribution of lattice and grain boundary to total conductivity was not separated nor where the activation energies for lattice and grain boundary conductivity determined [9]. These were done in the present study.

\section{Experimental}

\subsection{Powder Preparation}

$\mathrm{Li}_{1.2} \mathrm{Zr}_{1.9} \mathrm{Sr}_{0.1}\left(\mathrm{PO}_{4}\right)_{3}$ powder was prepared from $\mathrm{LiH}_{2} \mathrm{PO}_{4}$ (Chem-Impex Int'l.), $\mathrm{NH}_{4} \mathrm{H}_{2} \mathrm{PO}_{4}$ (Alfa Aesar), $\mathrm{ZrO}_{2}$ (Alfa Aesar) and $\mathrm{Sr}\left(\mathrm{NO}_{3}\right)_{2}$ (Alfa Aesar). The starting compounds were ground in a mortar with acetone as lubricant and then heated at $450^{\circ} \mathrm{C}$ in air for $30 \mathrm{~min}$, removed from the furnace, ground again and heated for a $2^{\text {nd }}$ time in air at $450^{\circ} \mathrm{C}$ for 30 min and then removed from the furnace. The powder was next pressed into a pellet and heated in air at $10^{\circ} \mathrm{C}$ per min to 
$1090^{\circ} \mathrm{C}$, held for $20 \mathrm{~h}$ and finally allowed to furnace cool. The pellet was ground into powder using a mortar and pestle.

\subsection{Consolidation}

The LZSPpowderswere hot-pressed at $1100^{\circ} \mathrm{C}$ under flowing argon at a constant pressure of 62 MPa for $1 \mathrm{~h}$ using a rapid induction hot-pressing technique $[17,18]$. The $1100^{\circ} \mathrm{C}$ temperature was reached within $5 \mathrm{~min}$. The cooling rate was $6^{\circ} \mathrm{C} / \mathrm{min}$.

\subsection{Sample Preparation}

LZSPsampleswere prepared for characterization and property evaluation using the following procedure. The hot-pressed LZSPdisc was sanded with 600 grit sandpaper until all of the graphite was removed from the two faces and further sanding was performed using 1200 grit sandpaper (Black Ice, Norton, Worcester, MA). Subsequent polishing was performed for half an hour on each side using a napless cloth with 15, 6, 1 and 0.5 micron grit diamond paste (Leco Corporation, St. Joseph, MI) on an autopolisher (Model 900, South Bay Technology Company, San Clemente, CA). After each step, a smooth and homogenous surface was verified by optical

microscopy. After final polishing the LZSPdisc was mounted and cut into samples using a diamond saw for characterization and evaluation.

\subsection{Density}


The bulk density of hot-pressed LZSPwas determined from the physical dimensions and mass.The bulk density was determined by dividing sample mass by the volume.The bulk density of the hot-pressed LZSPmaterial was also determined by the Archimedes method using hexane as the immersion fluid. The relative density was determined by dividing the bulk density by the theoretical density for LZSP, determined from measured lattice parameters $\left(3.14 \mathrm{~g} / \mathrm{cm}^{3}\right)$.

\subsection{X-Ray Diffraction}

X-ray Diffraction (XRD) was performed at $40 \mathrm{kV}$ and $100 \mathrm{~mA}$ by a Rigaku Rotating Anode XRay Diffractometer (Rigaku, Tokyo, Japan) using CuK $\alpha$ radiation with a wavelength of 1.54059 $\AA$ to determine phase purity and lattice parameters. XRD data was processed with Jade analysis software to assess the phases present in both the calcined powder and the hot-pressed LZSP.Lattice parameters were calculated from peak positions using Rietveld refinement.

\subsection{Microstructure}

The microstructure of the hot-pressed LZSPwas examined on uncoated fracture and polished surfacesusing scanning electron microscopy (SEM; Mira3 FEG-SEM, Tescan, Brno, Czech Republic with an accelerating voltage of $10 \mathrm{kV})$. The linear intercept grain size was determined from SEM fracture surfaces. At least 200 grains were measured. The Sr distribution in LZSPwas investigated in the SEM using energy dispersive X-ray spectroscopy (EDS) on polished surfaces in grain interior and regions near the grain boundaries, to look for $\mathrm{Sr}$ segregation at grain boundaries.

\subsection{Thermal Expansion}


The thermal expansion of hot-pressed LZSPwas measured by a thermomechanical analyzer (TA Instruments TMA 400). The data was analyzed by TMA Instruments Universal Analysis 2000 software. The sample was heated from room temperature to a maximum temperature of $500^{\circ} \mathrm{C}$ and held at that temperature for $1 \mathrm{~h}$. Subsequently, the sample was ramped down from $500^{\circ} \mathrm{C}$ to $50^{\circ} \mathrm{C}$ and then without pause it was ramped up from $50^{\circ} \mathrm{C}$ back to $500^{\circ} \mathrm{C}$. The sample was again held at $500^{\circ} \mathrm{C}$ for $1 \mathrm{~h}$, ramped down from $500^{\circ} \mathrm{C}$ to $50^{\circ} \mathrm{C}$ and then up from $50^{\circ} \mathrm{C}$ to $500^{\circ} \mathrm{C}$. The sample was held at $500^{\circ} \mathrm{C}$ for one more hour and then cooled to room temperature. The rate of heating/cooling was $5^{\circ} \mathrm{C} / \mathrm{min}$ for both cycles. Throughout the test, nitrogen gas flowed around the sample at a rate of $50 \mathrm{~mL} / \mathrm{min}$. Aluminum was used as a calibration standard.

\subsection{Conductivity}

The ionic conductivity of LZSP, was determined from electrochemical impedance spectroscopy (EIS) from $0.5 \mathrm{HZ}$ to $7 \mathrm{MHz}$ with a $100 \mathrm{mV}$ perturbation amplitude (Bio-Logic, Knoxville, TN, VMP300) over the temperature range 22 to $100^{\circ} \mathrm{C}$. Platinum was sputter coated on both sides of the hot-pressed discs to serve as a blocking electrode. The impedance spectra were modeled using a modified equivalent circuit (shown in Fig.5) [16]. The software program EC-Lab V10.30 was used for equivalent circuit modeling and each data set was normalized to the geometric dimensions of each disc to determine the total, grain boundary and bulk Li-ion conductivity values.

The electronic conductivity at room temperature was measured using DC polarization measurements at a voltage of $2 \mathrm{~V}$ [19]. The steady-state current and applied voltage were used to determine the resistance, which was converted to electronic conductivity using the specimen dimensions. 


\subsection{Elastic Modulus}

The elastic modulus, E, was determined using two techniques: 1] acoustic impulse excitation and 2] nanoindentation. Acoustic impulse excitation gives information on bulk polycrystalline elastic properties whereas, nanoindentation examines single grains within the sample. For the acoustic impulse excitation technique, two transducers were non-destructively coupled to the flat parallel sample LZSPsurfaces on opposing sides using a shear couplant (SWC, Olympus NDT) [ref]. Longitudinal acoustic pulses were generated and detected using M110 single element contact transducers and a 5073PR pulser-receiver (Olympus NDT, Tokyo, Japan). The pulse time, the time needed for the acoustic signal generated from one transducer and detected by the second transducer, to propagate through the sample, was measured by an oscilloscope (PicoScope 2207a, Pico Technologies, Cambridgeshire, UK). The longitudinal acoustic wavespeed, $\mathrm{v}_{\mathrm{L}}$, was calculated using the pulse time and the sample thickness measured by a micrometer. From the longitudinal wavespeed and using Poisson's ratio, $v=0.27$ [20], the elastic modulus can be calculated from the equation below [20]:

$\mathrm{E}=\mathrm{v}_{\mathrm{L}}^{2} \rho \frac{(1+v)(1-v)}{(1-2 v)}$

where $\rho$ is the density of LZSP. Nanoindentationexperiments were conductedusing aTI 950 TriboIndenter manufactured by Hysitron, (Minneapolis, MN, US) with a three-side pyramid Berkovichdiamond indenter. The elastic modulus was calculated from the load-displacement curve during unloading using the method described by Oliver-Pharr [22]. A $10 \mathrm{mN}$ load was used. Eleven measurements were made at this load. The maximum depth limit was about 500 nm. Fused silica was used as the standard reference material to calibrate the instrument. 


\subsection{Hardness}

Hardness was obtained using both Vickers and nanoindentation. Vickers hardness, $\mathrm{H}_{\mathrm{v}}$, was performed using a Mitutuyo hardness tester (Mitutoyo Corporation, Japan, HM122 V/K series 810). Before indentation, the Vickers hardness tester was calibrated using a steel hardness block (Vickers hardness test block; Mitutoyo Corporation, Hardness test Block HMV 700HV).The Vickers hardness was tested over range of loads from 0.49 to $9.81 \mathrm{~N}$ for an indentation time of 10 s. Five indents were made per load. In order to avoid the deformed region of the previous indent, each new indent was spaced farther than ten times the distance of the diagonal of all previous indents. Indents were also placed at least $1.5 \mathrm{~mm}$ away from the sample edge. Vickers hardness values were computed using the formula [23]:

$$
\mathrm{H}_{\mathrm{V}}=\frac{1.8544 \mathrm{P}}{(2 \mathrm{a})^{2}}(2)
$$

where 1.8544 is a constant specific to the Vickers geometry, $\mathrm{P}$ is the indentation load given in $\mathrm{GPa}$, and (2a) is the average of the indent diagonal lengths measured by optical microscopy immediately after indentation. Nanoindentationhardness was determined from the eleven indentations made at a load of $10 \mathrm{mN}$, which was also used to determine elastic modulus. This hardness was determined by the equation [22]:

$H=\frac{P_{\max }}{A_{C}}$

whereP $_{\max }$ refers to the maximum indentation load and $A_{C}$ is the projected contact area [22]. $A_{C}$ depends on the contact depth, which was determined by the slope of the unloading curve. These values weredeterminedusing TricoScan Software (Hysitron). 


\subsection{Fracture Toughness}

The fracture toughness ofLZSPwas determined using data from the Vickers indenter [24]. For fracture toughness measurements applied loads ranged from 0.49 to $9.61 \mathrm{~N}$. Crack lengths were measured by scanning electron microscopy. Identification and measurement of radial cracks resulting from Vickers indentation and related fracture toughness calculations were done as described by Anstiset al. [24]Fracture toughness, $\mathrm{K}_{\mathrm{IC}}$, was calculated using the equation below [24]:

$$
\mathrm{K}_{\mathrm{IC}}=0.016\left(\frac{\mathrm{E}}{\mathrm{H}}\right)^{\frac{1}{2}} \frac{\mathrm{P}}{(\mathrm{c})^{\frac{3}{2}}}
$$

where $\mathrm{c}$ is the crack length. Fracture toughness values were only determined from the data when the c/a was $>2$ [24].The $\mathrm{E}$ values were taken from the acoustic impulse excitation and nanoindentation results.

\subsection{Li Stability}

The chemical stability of LZSPagainst $\mathrm{Li}$ at room temperature was investigated using $\mathrm{Li} / \mathrm{Li}_{1.2} \mathrm{Zr}_{1.9} \mathrm{Sr}_{0.1}\left(\mathrm{PO}_{4}\right)_{3} / \mathrm{Li}$ symmetric cells. Cells were assembled and tested in an argon-filled glove box $\left(<0.2 \mathrm{ppm}_{2}\right.$ and $\left.<1 \mathrm{ppm} \mathrm{H}_{2} \mathrm{O}\right)$. Prior to cell assembly the LZSPsamplewas sanded with 600 grit sandpaper in the glove box to remove any surface contamination.Li foil was scraped to remove any surface oxide. A $465 \mathrm{~N}$ uniaxial force was applied to the cells to ensure constant pressure during cell testing. Electrochemical measurements were performed with a BioLogic system (Bio-Logic, Knoxville, TN, VMP300).The Li-LZSPinterfacial resistanceas a function of time was determined from Nyquist plots. After testing the $\mathrm{Li} / \mathrm{Li}_{1.2} \mathrm{Zr}_{1.9} \mathrm{Sr}_{0.1}\left(\mathrm{PO}_{4}\right)_{3} / \mathrm{Li}$ cells were dissembled and the $\mathrm{Li}_{1.2} \mathrm{Zr}_{1.9} \mathrm{Sr}_{0.1}\left(\mathrm{PO}_{4}\right)_{3}$ surfaces were examined for interaction with $\mathrm{Li}$. 


\subsection{Water Stability}

The water stability of LZSPwas determined at room temperature. Part of the LZSPhot-pressed disc was ground with mortar and pestle into powders. $0.25 \mathrm{~g}$ of powder was placed into $25 \mathrm{~cm}^{3}$ of distilled water in a sealed bottle and continually stirred. Prior to and periodically after immersion the $\mathrm{pH}$ of the solution was measured. The $\mathrm{pH}$ was measured until it appeared to reach a constant value with time. After testing the LZSPpowder was heated at $60^{\circ} \mathrm{C}$ for $24 \mathrm{~h}$ in air for XRD. The water stability of $\mathrm{Li}_{6.48} \mathrm{Al}_{0.24} \mathrm{La}_{3} \mathrm{Zr}_{2} \mathrm{O}_{12}, \mathrm{Li}_{0.33} \mathrm{La}_{0.57} \mathrm{TiO}_{3}$ and $\mathrm{Li}_{1.3} \mathrm{Ti}_{1.7} \mathrm{Al}_{0.3}\left(\mathrm{PO}_{4}\right)_{3}$ powders was also determined for comparison.

\section{Results and discussion}

\subsection{Density}

After hot-pressing the LZSPdiscwas white colored with a relative density 97\%. Both the physical and immersion techniques gave the same relative density.

\subsection{X-Ray Diffraction}

The X-ray diffraction plot of the hot-pressedLZSPalong with the reference pattern for $\mathrm{LiZr}_{2}\left(\mathrm{PO}_{4}\right)_{3}$ with the rhombohedral $\mathrm{R} \overline{3} \mathrm{c}$ space group are shown in Fig. 1. A comparison of the hot-pressed sample with the reference pattern reveals that the hot-pressed LZSPis predominately single phase with the desired rhombohedral $\mathrm{R} \overline{3}$ c space group. The Sr addition has stabilized the rhombohedral phaseat room temperature, similar to the effect of adding Ca or $\mathrm{Y}$ to $\mathrm{LiZr}_{2}\left(\mathrm{PO}_{4}\right)_{3}$

[8-11]. Rietveld refinement of the hot-pressed LZSPsample revealed it was composed of 98.4 
wt.\% $\mathrm{Li}_{1.2} \mathrm{Zr}_{1.9} \mathrm{Sr}_{0.1}\left(\mathrm{PO}_{4}\right)_{3}, 1.0$ wt.\% $\mathrm{ZrO}_{2}$ and 0.6 wt.\% $\mathrm{Li}_{3} \mathrm{PO}_{4}$ with $\mathrm{a}=8.8555(3) \AA$ and $\mathrm{c}=22.1952(1) \AA\left[\right.$ Volume $\left.=1507.4(1) \AA^{3}\right]$.

\subsection{Microstructure}

A scanning electron micrograph of the hot-pressed LZSPfracture surface is shown in Fig. 2. From Fig. 2 several important points are noted. Firstly, it can be seen that after hot-pressing the sample is very dense, very little porosity is observed, in agreement with the high relative density ( 97\%) determined using the physical dimensions and the Archimedes method. Secondly, the fracture mode is almost totally intergranular. Thirdly, the average linear intercept grain size is $\sim 10 \pm 1 \mu \mathrm{m}$. Fourthly, there is evidence of microcracking as shown by the arrows.Figure 3 is a scanning electron micrograph of a LZSPpolished surface showing the presence of both intergranular (dashed arrows) and intragranular (solid arrows) microcracks. In addition, EDS analysis revealed that Sr was uniformly distributed, no segregation to grain boundaries was observed.

\subsection{Thermal Expansion}

The linear expansion normalized by the original length versus temperature for hot-pressed LZSPfor the first heating/cooling cycle is shown in Fig. 4. The open symbols are from the cooling cycle, while the closed symbols are from the heating cycle. The data for the second cycle

nearly overlapped the first cycle data and hence, is not shown on Fig. 4. From Fig.4 several points are noted. Firstly, the sample undergoes a linear expansion which is negative then goes positive as the sample is cooled and then goes from negative to positive as it is heated. Secondly, 
there is a significant hysteresis loop between the heating and cooling cycles. Thirdly, after one cycle the sample does not return to its original dimension but, exhibits some permanent change. Examples of all of the above phenomena have been observed in $\mathrm{MM}_{2}^{\prime}\left(\mathrm{PO}_{4}\right)_{3}$ compounds where, $\mathrm{M}=\mathrm{Na}, \mathrm{K}, \mathrm{Cs}, \mathrm{Rb}$ and $\mathrm{M}^{\prime}=\mathrm{Zr}$, Ti[25]. It has been suggested that the above phenomena are associated with microcracking in these phosphates materials [11,12,25]. Consequently, the results of the thermal expansion studies confirm the microstructural observations (Figs. 2 and 3) that LZSP exhibits microcracking.

It has been shown by Cleveland and Bradt [26] that the critical grain size below which microcracking will not occur is inversely proportional to the square of the maximum difference in the thermal expansion coefficients (forrhombohedral LZSP the a and c directions) as shown in the equation below [26]:

$\mathrm{GS}_{\mathrm{cr}}=14.4 \gamma_{\mathrm{f}} /\left(\mathrm{E} \Delta \mathrm{T}^{2} \Delta \alpha_{\max }^{2}\right)$

where $\mathrm{GS}_{\mathrm{cr}}$ is the critical grain size for microcracking, $\gamma_{\mathrm{f}}$ is the fracture surface energy of a grain boundary, $\mathrm{E}$ is Young's modulus, $\Delta \mathrm{T}$ is the temperature range, and $\Delta \alpha_{\max }$ is the maximum difference in single crystal thermal expansion coefficients. From Eq.(5)the critical grain size for microcracking for LZSPcan be estimated. Inserting avalue of $10 \mathrm{~J} / \mathrm{m}^{2}$ for $\gamma_{\mathrm{f}}$ [27], E 115GPa for crack free materials with a NaSICON structure [11,12], $\Delta \mathrm{T}=1050^{\circ} \mathrm{Cand} \Delta \alpha_{\max }=23 \times 10^{-6 \circ} \mathrm{C}^{-1}$ for $\mathrm{Li}_{1} \mathrm{Zr}_{2}\left(\mathrm{PO}_{4}\right)_{3}$ with the $\mathrm{R} \overline{3} \mathrm{c}$ space group [28]yieldsGS $\mathrm{cr}_{\mathrm{r}} \sim \mu \mathrm{m}$. The observed grain size is $\sim 10 \mu \mathrm{m}$ which is greater than the critical grain size and hence, microcracking is predicted and is indeed observed in the micrographs (Figs. 2 and 3) and the thermal expansion curves (Fig. 4).

\subsection{Conductivity}


The room temperature Nyqusit plot for LZSPand the equivalent circuit (inset) used to analyze the data are shown in Fig.5. The markers indicate the experimental data and the solid lines are simulated lines extrapolated from the equivalent circuit shown. In the inset, $\mathrm{R}$ refers to resistance, $\mathrm{CPE}$ to constant phase element, and $\mathrm{M}_{\mathrm{a}}$ to anomalous mass diffusion, which is related to the reaction between Pt and Li [11]). The subscripts uncomp, geo, bulk, gb and int, represent, uncompensated, geometric dimensions, bulk, grain boundary, interfacial (surface roughness and nonideality of the Pt blocking electrodes) phenomena, respectively. The semicircles (left to right) represent the bulk and grain-boundaryresistances.

From Fig.5 several important points are noted. Firstly, the appearance of an inclined spike at low frequencies is an indication that LZSPisan ionic conductor [29,30]. Secondly, the bulk Li-ion conductivity of LZSPat room temperature is $0.83 \times 10^{-4} \mathrm{~S} / \mathrm{cm}$. This is can be compared to other "Li stable" NaSICON framework materials with the rhombohedral $\mathrm{R} \overline{3} \mathrm{c}$ space group, $\mathrm{Li}_{1.2} \mathrm{Zr}_{1.9} \mathrm{Ca}_{0.1}\left(\mathrm{PO}_{4}\right)_{3}[7,8]$ and $\mathrm{Li}_{1.15} \mathrm{Y}_{0.15} \mathrm{Zr}_{1.85}\left(\mathrm{PO}_{4}\right)_{3}[10]$, where bulk Li-ion conductivities of $1.2 \times 10^{-4}$ and $1.4 \times 10^{-4} \mathrm{~S} / \mathrm{cm}$ have reported, respectively. No bulk conductivity was reported for $\mathrm{Li}_{1.2} \mathrm{Zr}_{1.9} \mathrm{Sr}_{0.1}\left(\mathrm{PO}_{4}\right)_{3}$ [9]. Reasons for the slight difference in bulk conductivity between $\mathrm{Li}_{1.2} \mathrm{Zr}_{1.9} \mathrm{Sr}_{0.1}\left(\mathrm{PO}_{4}\right)_{3}$ and $\mathrm{Li}_{1.2} \mathrm{Zr}_{1.9} \mathrm{Ca}_{0.1}\left(\mathrm{PO}_{4}\right)_{3}$ and $\mathrm{Li}_{1.15} \mathrm{Y}_{0.15} \mathrm{Zr}_{1.85}\left(\mathrm{PO}_{4}\right)_{3}$ are not known, since they all have about the same unit cell volume $\left(\mathrm{Li}_{1.2} \mathrm{Zr}_{1.9} \mathrm{Sr}_{0.1}\left(\mathrm{PO}_{4}\right)_{3} ;\right.$ Volume $=1507 \AA^{3}, \mathrm{Li}_{1.2} \mathrm{Zr}_{1.9} \mathrm{Ca}_{0.1}\left(\mathrm{PO}_{4}\right)_{3} ;$ Volume $=1505 \AA^{3} ; \mathrm{Li}_{1.15} \mathrm{Y}_{0.15} \mathrm{Zr}_{1.85}\left(\mathrm{PO}_{4}\right.$ )$_{3}$; Volume $=1510 \AA^{3}$ ) and nearly the same nominal Li content. The bulk conductivities of above three "Li stable" NaSICON framework can be compared to another Li stable conducting solid electrolyte, cubic LLZO. The bulk conductivities of the above NaSICON materialsareabout 4 times lower than Al stabilized and 8 lower than Ta stabilized LLZO [2]. Fourthly, the total conductivity of LZSPat room temperature is $2.1 \times 10^{-5} \mathrm{~S} / \mathrm{cm}$. This is in close agreement with the 
value of $3.4 \times 10^{-5} \mathrm{~S} / \mathrm{cm}$ measured for $\mathrm{Li}_{1.2} \mathrm{Zr}_{1.9} \mathrm{Sr}_{0.1}\left(\mathrm{PO}_{4}\right)_{3}$ by the recent study of similar density and grain size [9]. It is lower than that exhibited by $\mathrm{Li}_{1.2} \mathrm{Zr}_{1.9} \mathrm{Ca}_{0.1}\left(\mathrm{PO}_{4}\right)_{3}$ of $4.9 \times 10^{-5} \mathrm{~S} / \mathrm{cm}$ of similar relative density (95.7\%) and grain size $(\sim 7 \mu \mathrm{m})$ and $\mathrm{Li}_{1.15} \mathrm{Y}_{0.15} \mathrm{Zr}_{1.85}\left(\mathrm{PO}_{4}\right)_{3} \mathrm{Of} 7.1 \times 10^{-5}$ S/cm of relative density (90\%) and grain size $(\sim 5 \mu \mathrm{m})$. The total conductivity of LLZO at relative density of greater than $95 \%$ and similar grain size is much higher, with values between 5 $\mathrm{x} 10^{-4}$ to $10^{-3} \mathrm{~S} / \mathrm{cm}$ [2]. It is of interest to note that grain boundary resistance to the total resistance is about $51 \%$ for $\mathrm{Li}_{1.15} \mathrm{Y}_{0.15} \mathrm{Zr}_{1.85}\left(\mathrm{PO}_{4}\right)_{3}$ consolidated by spark plasma sintering and 74\% for LZSPconsolidated by hot-pressing. This is very high compared to only $8 \%$ for hotpressed Al-stabilized LLZO [10] and most likely has to do with microcracking along grain boundaries for the NaSICON materials, where none occurs in LLZO, as a result of its cubic structure.

The electronic conductivity, $\sigma_{\text {electronic, }}$ of LZSPatroom temperature is a about $5 \times 10^{-9} \mathrm{~S} / \mathrm{cm}$. No electronic conductivity values were reported for $\mathrm{Li}_{1.2} \mathrm{Zr}_{1.9} \mathrm{Ca}_{0.1}\left(\mathrm{PO}_{4}\right)_{3}$ and $\mathrm{Li}_{1.15} \mathrm{Y}_{0.15} \mathrm{Zr}_{1.85}\left(\mathrm{PO}_{4}\right)_{3}$. Theelectronic conductivity value measured by this study is in good agreement with value of $10^{-8} \mathrm{~S} / \mathrm{cm}$ measured by the recent study onLi $\mathrm{i}_{1.2} \mathrm{Zr}_{1.9} \mathrm{Sr}_{0.1}\left(\mathrm{PO}_{4}\right)_{3}[9]$. The ionic transport number, $\mathrm{t}_{\text {ionic }}$, for $\mathrm{Li}$-ions in $\mathrm{Li}_{1.2} \mathrm{Zr}_{1.9} \mathrm{Sr}_{0.1}\left(\mathrm{PO}_{4}\right)_{3}$, $\left[\mathrm{t}_{\text {ionic }}=\sigma_{\text {ionic }} / \sigma_{\text {total }}\right.$, where $\sigma_{\text {total }}=\sigma_{\text {ionic }}+\sigma_{\text {electronic }} ; \sigma_{\text {ionic }}$ is the total ionic conductivity]is about 1 , confirming that $\mathrm{Li}_{1.2} \mathrm{Zr}_{1.9} \mathrm{Sr}_{0.1}\left(\mathrm{PO}_{4}\right)_{3}$, is an ionic conductor.

Figure 6 is an Arrhenius plot of total conductivity, bulk and grain boundary conductivity for hotpressed LZSP. From Fig.6 it can observed the over temperature range investigated (22$100^{\circ} \mathrm{C}$ )the total conductivity of LZSPis mainly controlled by grain boundary conductivity. The activation energy for bulk, grain boundary and total conductivity determined from the slope of the line is $0.29,0.36$ and $0.32 \mathrm{eV}$, respectively. The activation energy for bulk conductivity of 
LZSP(0.29 eV)isclose to values reported for other Li-ion conductors [2,4,5,31-33]. No activation energy for bulk conductivity is reported for $\mathrm{Li}_{1.2} \mathrm{Zr}_{1.9} \mathrm{Ca}_{0.1}\left(\mathrm{PO}_{4}\right)_{3}$ andLi $\mathrm{i}_{1.15} \mathrm{Y}_{0.15} \mathrm{Zr}_{1.85}\left(\mathrm{PO}_{4}\right)_{3}$. In addition, no grain boundary conductivity activation energy is reported for $\mathrm{Li}_{1.2} \mathrm{Zr}_{1.9} \mathrm{Ca}_{0.1}\left(\mathrm{PO}_{4}\right)_{3}$ andLi ${ }_{1.15} \mathrm{Y}_{0.15} \mathrm{Zr}_{1.85}\left(\mathrm{PO}_{4}\right)_{3}$. The activation energy for total $\mathrm{Li}_{1.2} \mathrm{Zr}_{1.9} \mathrm{Sr}_{0.1}\left(\mathrm{PO}_{4}\right)_{3}$ conductivity $(0.32 \mathrm{eV})$ is in agreement with the values reported for $\mathrm{Li}_{1.15} \mathrm{Y}_{0.15} \mathrm{Zr}_{1.85}\left(\mathrm{PO}_{4}\right)_{3}(0.39 \mathrm{eV}[10])$ but lower than that for $\mathrm{Li}_{1.2} \mathrm{Zr}_{1.9} \mathrm{Ca}_{0.1}\left(\mathrm{PO}_{4}\right)_{3}(0.48 \mathrm{eV}[7,8])$ and $\mathrm{Li}_{1.2} \mathrm{Zr}_{1.9} \mathrm{Sr}_{0.1}\left(\mathrm{PO}_{4}\right)_{3}(0.39 \mathrm{eV}[10])$ measured in the recent study.

\subsection{Elastic Modulus}

TheYoung's modulus determined using acoustic impulse excitation and nanoindentationfor LZSPis25 \pm 5 and $41 \pm 9 \mathrm{GPa}$, respectively. It is observed that Young's modulus determined from nanoindentationis higher than that measured using acoustic impulse excitation. This is not unexpected because, nanoindentation provides quasi-single-crystal behavior (within the grains) while pulse impulse excitation provides isotropic bulk polycrystalline analysis which includes both grain and grain boundaries. It is known that the presence of microcracks leads to a reduction in elastic modulus [11,12,14,15]. From Figs. 2 and 3 it is observed that a majority of the microcracksare primarilyalong grain boundaries. Thus, a low modulus is expected for techniques that sample the bulk (acoustic impulse excitation) compared to those which only sample within grains (nanoindentation). The Young's modulus determined using nanoindentation can be compared to values for other NaSICONmaterials at grain sizes below the critical grain size where no microcracks exist and theoretical predictions using density functional theory (DFT). The experimental modulus values for NaSICON materials based on a zirconium and titanium phosphate framework structure with no microcracksis between 100-120 GPa. [11,14]. DFT 
predicts a value for Young's modulus of $\mathrm{LiTi}_{2}\left(\mathrm{PO}_{4}\right)_{3} \sim 144 \mathrm{GPa}$ and $\mathrm{NaZr}_{2}\left(\mathrm{PO}_{4}\right)_{3} \sim 121 \mathrm{GPa}$ [20]. These values are higher than the value for LZSPdetermined by nanoindentation (40.9 GPa) by a factor of about 2-3. It is surprising why such a large difference exists. Examination of Fig.3revealsevidence of microcracksnot only at grain boundaries but, also within the grains (solid arrows). The presence of microcracks within grains at large grain size has observed in other NaSICONmaterialsexhibiting anisotropic thermal expansion coefficients $[12,13]$. Thus, it is highly likely that the presence of intragranularmicrocracksleads to low values of Young's modulus for LZSPdetermined using nanoindentation. If the grain size of LZSPis less thenthe critical grain size $(\sim 4 \mu \mathrm{m})$ a Young's modulus with a value around 110-120 GPawould be expected. No modulus data for $\mathrm{Li}_{1.2} \mathrm{Zr}_{1.9} \mathrm{Ca}_{0.1}\left(\mathrm{PO}_{4}\right)_{3}$ andLi $\mathrm{i}_{1.15} \mathrm{Y}_{0.15} \mathrm{Zr}_{1.85}\left(\mathrm{PO}_{4}\right)_{3}$ have been reported.

\subsection{Hardness}

Figure 7 is a plot of Vickers hardness for LZSPversus applied load. From Fig. 7 a dependence of Vickers hardness on applied load is exhibited. This is a common phenomenon in materials and is known as the indentation size effect [35-37]. From Fig. 7 it is observed that Vickers hardness decreases with increasing load. The Vickers hardness value in the load independent region is 2.2 \pm 0.4 GPa. The nanoidentationhardness ( $3.3 \pm 1.3 \mathrm{GPa}$ ) is higher than the Vickers hardness. This is expected since, the indent impression size for Vickers is between 10 to $50 \mu \mathrm{m}$. This is larger than the average grain size $(\sim 10 \mu \mathrm{m})$ thus, the Vickers results will be affected by the grain boundaries while the indent impression for nanoidenation is $1 \mu \mathrm{m}$ or less, which is smaller than the grain size. Since, many of the grain boundaries exhibit microcracking (Figs. 2 and 3) a lower hardness is expected and is observed for the Vickers hardness compared to the nanoindentation hardness. No hardness results are available for $\mathrm{Li}_{1.2} \mathrm{Zr}_{1.9} \mathrm{Ca}_{0.1}\left(\mathrm{PO}_{4}\right)_{3}$ andLi $\mathrm{Li}_{1.15} \mathrm{Y}_{0.15} \mathrm{Zr}_{1.85}\left(\mathrm{PO}_{4}\right)_{3}$. 
The Vickers hardnessvalues for LZSPcan be compared to Vickers hardness values for other NaSICON structures such as; $\mathrm{Na}_{3.2} \mathrm{Zr}_{2} \mathrm{Si}_{3.2} \mathrm{P}_{0.8} \mathrm{O}_{12}(\sim 4.9 \mathrm{GPa})$ [38] and $\mathrm{Sc}_{1.3} \mathrm{Zr}_{2}\left(\mathrm{PO}_{4}\right)_{3}(\sim 3.8 \mathrm{GPa})$ [39]. The Vickershardnessvalue for $\mathrm{Li}_{1.2} \mathrm{Zr}_{1.9} \mathrm{Sr}_{0.1}\left(\mathrm{PO}_{4}\right)_{3}$ is lower than those for $\mathrm{Na}_{3.2} \mathrm{Zr}_{2} \mathrm{Si}_{3.2} \mathrm{P}_{0.8} \mathrm{O}_{12}$ and $\mathrm{Sc}_{1.3} \mathrm{Zr}_{2}\left(\mathrm{PO}_{4}\right)_{3}$. Several reasonsare possible for this difference. Firstly, it could be do a difference in grain size since, it is known that hardness increases with decreasing grain size $[27,40]$. No grain sizes are listed for the above materials. Secondly, it could be a result of microcracking. No published microstructures are available to see if microcracks are present in the above materials.

\subsection{Fracture Toughness}

The fracture toughness values for LZSPdetermined using data from a Vickers indenter (H, P, c) along with E values determined from acoustic impulse excitation and nanoindentation. It was observed that $\mathrm{K}_{\mathrm{IC}}$ was independent of load. The $\mathrm{K}_{\mathrm{IC}}$ valuefor is $0.29 \pm 0.05$ and $0.37 \pm 0.07 \mathrm{MPa}$ $\mathrm{m}^{1 / 2}$ using $\mathrm{E}$ determined from acoustic impulse excitation and nanoindentation, respectively. In general ceramics exhibit fracture toughness values from $\sim 0.5$ to $5 \mathrm{MPa}-\mathrm{m}^{1 / 2}$, with values between $\sim 0.5$ to 2 MPa-m ${ }^{1 / 2}$ for single crystals and for polycrystals between $\sim 2$ to 5 MPa-m ${ }^{1 / 2}[41,42]$. The $\mathrm{K}_{\mathrm{IC}}$ values for LZSPare near the low end of single crystal values. This observation suggests that $\mathrm{Li}_{1.2} \mathrm{Zr}_{1.9} \mathrm{Sr}_{0.1}\left(\mathrm{PO}_{4}\right)_{3}$ is extremely brittle like glass. The very low $\mathrm{K}_{\mathrm{ICC}}$ is most likely a result of microcracking. No $\mathrm{K}_{\mathrm{IC}}$ values for $\mathrm{Li}_{1.2} \mathrm{Zr}_{1.9} \mathrm{Ca}_{0.1}\left(\mathrm{PO}_{4}\right)_{3}$ andLi $\mathrm{L}_{1.15} \mathrm{Y}_{0.15} \mathrm{Zr}_{1.85}\left(\mathrm{PO}_{4}\right)_{3}$ have been reported. Fracture toughness has been measured in another NaSICON material, $\mathrm{Li}_{1.3} \mathrm{Ti}_{1.7} \mathrm{Al}_{0.3}\left(\mathrm{PO}_{4}\right)_{3}(\mathrm{LATP})$ of similar relative density ( 96\%) but of smaller grain size $(\sim 1.7$ $\mu \mathrm{m})$ [14]. For LATP $\mathrm{K}_{\mathrm{IC}} \sim 1.1 \mathrm{MPa}-\mathrm{m}^{1 / 2}$ measured using a single-edge precracked beam. This is also at the low end of fracture toughness values for ceramics, confirming the brittleness of 
NaSICON materials. The higher value of LATP compared to LZSPis most likely a result of its smaller grain size, resulting in less microcracking. The actual grain size $\sim 1.7 \mu \mathrm{m}$ for LATP is close to the predicted critical grain size $(\sim 1.6 \mu \mathrm{m})$ for microcracking [14]. For the case of LZSPthe actual grain size is $\sim 10 \mu \mathrm{m}$, this is greater than the predicted critical grain size $(\sim 4 \mu \mathrm{m})$ for microcracking. Hence, more microcracking is expected in LZSPcompared to LATP leading to reduced mechanical properties such as; lower fracture toughness and elastic modulus in LZSPcompared to LATP.

\subsection{Li Stability}

The stability of LZSPagainst Li at room temperature was investigated using EIS. Figure 8 shows a Nyquist plot of the impedance spectra as a function of time forLi/Li $1.2 \mathrm{Zr}_{1.9} \mathrm{Sr}_{0.1}\left(\mathrm{PO}_{4}\right)_{3} / \mathrm{Li}$ symmetric cells and the equivalent circuit used to separate the LZSP resistance $\left(\mathrm{R}_{\text {total }}\right)$ from the Li-LZSP interfacial resistance $\left(\mathrm{R}_{\text {interface }}\right)$. The impedance spectra was composed of two semicircles. The first semi-circle in the high frequency range is attributed to the LZSP resistance $\left(\mathrm{R}_{\text {total }}\right)$. This semi-circle is composed of the bulk and grain boundary resistance. The second semi-circle at lower frequency is attributed to the interfacial resistance between LZSPand the Li electrode $\left(R_{\text {interface }}\right)$ [29,42-45]. From Fig. 8 it can observed that the resistance $\left(R_{\text {total }}+\right.$

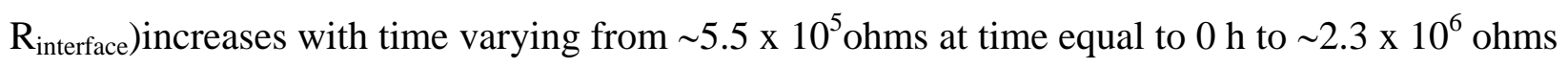
at $230 \mathrm{~h}$. Because of the low value of the LZSP resistance $\left(\mathrm{R}_{\text {total }}\right) \sim 1 \times 10^{4}$ ohms(which did not vary with time) compared to the large value of the resistance $\left(\mathrm{R}_{\text {total }}+\mathrm{R}_{\text {interface }}\right)$ observed (5.5 x $10^{5}$ to $\left.2.3 \times 10^{6}\right)$, the high-frequency semi-circle for the LZP resistance $\left(\mathrm{R}_{\mathrm{total}}\right)$ is not visible in the plot. Hence, the resistance shown by the semi-circle in Fig. 8 is associated almost entirelywith 
the interfacial resistance $\left(\mathrm{R}_{\text {interface }}\right)(\sim 96 \%$ at $\mathrm{t}=0$ to $\sim 100 \%$ at $\mathrm{t}=230 \mathrm{~h}$ ) between LZSPand the Li electrode. From Fig. 8 it is observed that the interfacial resistance is increasing with time. In order to determine the dependence of this interfacial resistance on time, the interfacial resistance was plotted as area specific resistance versus time. This plot is shown in Fig. 9. From Fig.9it is noted that the resistance increases linearly with time. At $230 \mathrm{~h}$ the resistance is still increasing at a constant rate, there is no decrease in rate or levelling off with time. This observation suggeststhatLZSPis not stable with $\mathrm{Li}$ at room temperature. Fig. 10 is an optical image of the LZSPsurfaceafter contact with the metallic Li electrode. From Fig. 10 it is observed that the LZSPsurface became black after contact with metallic Li suggesting some reaction since, it was initially colored white prior to contact. Attempts to identify the black region by x-ray photoelectron spectroscopy were unsuccessful. The impedance data (Figs. 8 and 9) and the surface examination (Fig. 10) results confirm that LZSPis not stable against metallic Li. This is surprising in that it was believed [7] since, they contain no transition metal cations, that lithium zirconium phosphates would be stable against metallic $\mathrm{Li}$ at room temperature. To further confirm this instability a dense (relative density 97\%) $\mathrm{Li}_{1.2} \mathrm{Zr}_{1.9} \mathrm{Ca}_{0.1}\left(\mathrm{PO}_{4}\right)_{3}$ pellet was prepared and placed in contact with metallic Li. This pellet which was initially white turned black after contact with Li,confirming lithium zirconium phosphates instability against Li.

\subsection{Water Stability}

Figure 11 is a plot of $\mathrm{pH}$ for distilled water as a function of time for the reaction between $\mathrm{Li}_{1.2} \mathrm{Zr}_{1.9} \mathrm{Sr}_{0.1}\left(\mathrm{PO}_{4}\right)_{3}, \mathrm{Li}_{6.48} \mathrm{Al}_{0.24} \mathrm{La}_{3} \mathrm{Zr}_{2} \mathrm{O}_{12}, \mathrm{Li}_{0.33} \mathrm{La}_{0.57} \mathrm{TiO}_{3}$ and $\mathrm{Li}_{1.3} \mathrm{Ti}_{1.7} \mathrm{Al}_{0.3}\left(\mathrm{PO}_{4}\right)_{3}$ powders and water at room temperature. The initial $\mathrm{pH}$ for distilled water wasabout 6.9. From Fig. 11 several points are noted. Firstly, after $1 \mathrm{~h}$ the $\mathrm{pH}$ of for all solutions increased. Secondly, for the 
$\mathrm{Li}_{6.48} \mathrm{Al}_{0.24} \mathrm{La}_{3} \mathrm{Zr}_{2} \mathrm{O}_{12}$, and $\mathrm{Li}_{0.33} \mathrm{La}_{0.57} \mathrm{TiO}_{3}$ powders the $\mathrm{pH}$ increases then reaches a steady-state value, whereas for theLZSPand $\mathrm{Li}_{1.3} \mathrm{Ti}_{1.7} \mathrm{Al}_{0.3}\left(\mathrm{PO}_{4}\right)_{3}$ powders after the initial increase the $\mathrm{pH}$ decreases before a steady-state value is reached. Thirdly, the steady-state $\mathrm{pH}$ value for the $\mathrm{Li}_{6.48} \mathrm{Al}_{0.24} \mathrm{La}_{3} \mathrm{Zr}_{2} \mathrm{O}_{12}$ and $\mathrm{Li}_{0.33} \mathrm{La}_{0.57} \mathrm{TiO}_{3}$ powders, 12.74 and 12,24, respectively, is much higher than the steady-state values for LZSPand $\mathrm{Li}_{1.3} \mathrm{Ti}_{1.7} \mathrm{Al}_{0.3}\left(\mathrm{PO}_{4}\right)_{3}, 7.41 .7 .01$, respectively. The increase in $\mathrm{pH}$ is associated with protons from the water entering the lattice with $\mathrm{OH}^{-}$ions remaining leading to an increase in ${ }_{\mathrm{p}} \mathrm{H}$ of the solution [47,48]. From Fig. 11 it is observed that lithium phosphates are more stable in water than the garnet and perovskite oxides. X-ray diffraction of LZSPafter water immersion revealed no change in structure. Thus, based on water stability LZSPis a possible membrane for use in the aqueous Li-Air system.

\section{Conclusions}

$\mathrm{Li}_{1.2} \mathrm{Zr}_{1.9} \mathrm{Sr}_{0.1}\left(\mathrm{PO}_{4}\right)_{3}(\mathrm{LZSP})$ powders were prepared and consolidated by reactive hot-pressing. The addition of Sr stabilized the rhombohedral $\mathrm{R} \overline{3} \mathrm{c}$ structure at room temperature. The hotpressed material had a relative density of $\sim 97 \%$, a linear intercept grain size of $\sim 10 \mu \mathrm{m}$, an intergranular fracture mode and microcracks along grain boundaries and within grain interiors. Thermal expansion results (e.g., hysteresis) are in agreement with the presence of microcracks. It is suggested that a grain size of less than $\sim 4 \mu \mathrm{m}$ is required to prevent microcracking.The lattice conductivity of LZSP is $0.85 \times 10^{-4} \mathrm{~S} / \mathrm{cm}$ with an activation energy for bulk conductivity of 0.29 $\mathrm{eV}$,in agreement with values for other lithium zirconium phosphates. The total ionic conductivity ofLZSPatroom temperature is $2.1 \times 10^{-5} \mathrm{~S} / \mathrm{cm}$ and is controlled by the grain boundary contribution. Measurement of the electronic conductivity confirmed that LZSP is an ionic conductor with anionic transport number $\sim 1$. The elastic modulus for LZSP determined by 
nanoindentation is $40.9 \mathrm{GPa}$, which is higher than that measured using acoustic impulse excitation of 25.2 GPa.Fracture toughness values for LZSPare less than $0.5 \mathrm{MPa}-\mathrm{m}^{1 / 2}$. These low fracture toughness values suggests that LZSPis extremely brittle. The low elastic modulus and fracture toughness and total ionic conductivity values forLZSP are result of microcracking. The results of $\mathrm{Li} / \mathrm{LZSP} / \mathrm{Li}$ cell impedance and surface examination suggest that LZSP is not stable against metallic Li. Water stability results suggest that LZSP could be a possible membrane for use in the aqueous Li-Air system.

The main results of this study for the case of lithium zirconium phosphates are as follows: 1] a small grain size is required to prevent microcracking to avoid a reduction in total conductivity and mechanical properties and 2] even though they do not contain a transition metal cation they are not stable against $\mathrm{Li}$ at room temperature.

\section{Acknowledgements}

JW and JAL would like to acknowledge support of the Army Research Laboratory. This work was supported by the U.S. Department of Energy(DE-EE-00006821).

\section{References}

[1] P.G. Bruce, S. A. Freunberger, L. J. Hardwick, J.-M. Tarascon, Nat. Mater. 11 (2011) 19-29.

[2] J. L. Allen, J. Wolfenstine, E. Rangasamy, J. Sakamoto, J. Power Sources 206 (2012) 315319.

[3] J. B. Goodenough, Y. Kim, Chem. Mater. 22 (2009) 587-603.

[4] P. Knauth, Solid State Ionics 180 (2009) 911-916.

[5] J. W. Fergus, J. Power Sources 195 (2010) 4554-4569.

[6] J. B. Goodenough, Proc. R. Soc. Lond. A 393 (1984) 215-234.

[7] H. Xie, Y. Li, J. B. Goodenough, RSC Adv. 1 (2011) 1728-1731.

[8] H. Xie, J. B. Goodenough, Y. Li, J. Power Sources 196 (2011) 7760-7762.

[9] S. Kumar, P. Palani, Solid State Ionics 296 (2016) 1-6

[10] Y. Li, M. Liu, K. Liu, C.-A.Wang, J. Power Sources 240 (2013) 50-53.

[11] I. Yamai, T. Ota, J. Am. Ceram. Soc. 76 (1995) 487-491. 
[12] T. Ota, I. Yamai, J. Am. Ceram. Soc. 69 (1986) 1-6.

[13] T. Huper, E. C. Bucharsky, K. G. Schell, A. Senyshen, M. Monchak, M. J. Hoffmann, H. Ehrenberg,Solid State Ionics 288 (2016) 235-239.

[14] S. D. Jackman, R. A. Cutler, J. Power Sources 218 (2012) 65-72.

[15] Y. Kim, E. D. Case, S. Gaynor, J. Mater. Sci. 18 (1993) 1910-1918.

[16] E. D. Case, J. Mater. Sci. Lett. 19 (1984) 3702-3712.

[17] I. N. David, T. Thompson, J. Wolfenstine, J. L. Allen, J. Sakamoto, J. Am. Ceram. Soc. 98 (2015) 1209-1214.

[18] Y. Kim,. J. Ho, H. Choe, J. L. Allen, J. Wolfenstine, J. Sakamoto, J. Am. Ceram. Soc. 99

(2016) 1367-1374.

[19] J. L. Allen, T. Thompson, J. Sakamoto, C. R. Becker, T. R. Jow, J. Wolfenstine, J. Power Sources 254 (2014) 204-208.

[20] Z. Deng, Z. Wang, I.-H. Chu, J. Luo, S. P. Ong, J. Electrochem. Soc. 163 (2016) A67-A74.

[21] S. Yu, R. D. Scmidt, R. Garcia-Mendez, E. Herbert, N. J. Dudney, J. Wolfenstine, J.

Sakamoto, D. J. Siegel, Chem. Mater. 28 (2016) 197-206.

[22] W. C. Oliver, G. M. Pharr, J. Mater. Res. 7 (1992) 1564-1583.

[23] J. Ni, E. D. Case, J. S. Sakamoto, E. Rangasamy, J. B. Wolfenstine, J. Mater. Sci. 47 (2012) 7978-7985.

[24] G. R. Antis, P. Chantikul, B. R. Lawn, D. B. Marshall, J. Am. Ceram. Soc. 64 (1981) 533538.

[25] C.-Y Huang, D. K. Agrawal, H. A. McKinstry J. Mater. Sci. 30 (1995) 3509-3514.

[26] J. J. Cleveland, R. C. Bradt, J. Am. Ceram. Soc. 61 (1978) 478-481.

[27] R. W. Davidge, Mechanical Behavior of Ceramics, Cambridge University Press, Cambridge,

1979.

[28] J. Alamo, J. L. Rodrigo, Solid State Ionics 32/33 (1989) 70-76.

[29] R. A. Huggins, Ionics 8 (2002) 300-313.

[30] J. T. S. Irvine, D. C. Sinclair, A. R. West, Adv. Mater. 2 (1990) 132-138.

[31] R. Djenadic, M. Botros, C. Benel, O. Clemens, S. Indris, A. Choudhary, T. Bergfeldt, H. Han, Solid State Ionics 263 (2014) 49-56.

[32] G.-Y. Adachi, N. Imanaka, H. Aono, Adv. Mater. 8 (1996) 127-135.

[33] S. Starmare, V. Thangadurai, W. Weppner, Chem. Mater. 15 (2003) 3974-3990.

[34] V. Thangadurai, D. Pinzaru, S. Narayanan, A.K. Baral, J. Phy. Chem. Lett. 6 (2015) 292299.

[35] H. Li, R. C. Bradt, J. Mater. Sci. Lett. 31 (1996) 1065-1070.

[36] M. E. Stevenson, M. Kaji, R. C. Bradt, J. Euro. Ceram. Soc. 22 (2002) 1137-1148.

[37] A. Chanda, B. X. Huang, J. Malzbender, R. W. Steinbrech, J. Euro. Ceram. Soc. 31 (2011)

401-408.

[38] V. Bogusz, F. Krok, W. Jakubowski, Solid State Ionics $9 \& 10$ (1983) 803-808.

[39] N. Imanaka, G.-Y.Adachi, J. Alloy Comp. 344 (2002) 137-140.

[40] R. W. Rice, Mechanical Properties of Ceramics and Composites, Marcel Dekker Inc., New York, 2000.

[41] Y.-M. Chiang, D. Birnie, W. D. Kingery, Physical Ceramics, John Wiley \& Sons, New York,

1997.

[42] M. V. Barsum, Fundamentals of Ceramics, The McGraw Hill Companies, Inc., New York, 
1997.

[43] A. Sharafi, H. M. Meyer, J. Nanda, J. Wolfenstine, J. Sakamoto, J. Power Sources 302 (2016) 135-139.

[44] S. Wenzel, D. A. Weber, T. Leichtweiss, M. R. Busche, J. Sann, J. Jannek, Solid State Ionics 286 (2016) 24-33.

[45] S. Wenzel, S. Randau, T. Leichtweiss, D. A. Weber, J. Sann, W. G. Zeiler, J. Janek, Chem. Mater. 28 (2016) 2400-2407.

[46] Y. Kim, A. Yoo, R. Schmidt, H. Lee, J. Wolfenstine, J. Sakamoto, Front. Energy. Res., 4 (2016) 1-7.

[47] A. Boulant, P. Maury, J. Emery, J.-Y. Buzare, O. Bohnke, Chem. Mater. 21 (2009) 22092417.

[48] J. Wolfenstine, J. L. Allen, J. Mat. Sci.43 (2008) 7247-7249.

\section{List of Figures}

Fig. 1. X-ray diffraction pattern of hot-pressed $\mathrm{Li}_{1.2} \mathrm{Zr}_{1.9} \mathrm{Sr}_{0.1}\left(\mathrm{PO}_{4}\right)_{3}$ and reference pattern for $\mathrm{LiZr}_{2}\left(\mathrm{PO}_{4}\right)_{3}$ with the rhombohedral R$\overline{3} \mathrm{c}$ space group (PDF \#01-084-0998).

Fig. 2. Scanning electron microscopy image of $\mathrm{Li}_{1.2} \mathrm{Zr}_{1.9} \mathrm{Sr}_{0.1}\left(\mathrm{PO}_{4}\right)_{3}$ fracture surface. Arrows indicate microcracking.

Fig. 3. Scanning electron microscopy image of $\mathrm{Li}_{1.2} \mathrm{Zr}_{1.9} \mathrm{Sr}_{0.1}\left(\mathrm{PO}_{4}\right)_{3}$ polished surface. Solid arrows indicate intragranularmicrocracks. Dotted arrows indicate intergranular microcracks.

Fig. 4. Thermal expansion plot of $\mathrm{Li}_{1.2} \mathrm{Zr}_{1.9} \mathrm{Sr}_{0.1}\left(\mathrm{PO}_{4}\right)_{3}$ as a function of temperature. Open symbols represent the cooling cycle. Closed symbols represent the heating cycle.

Fig. 5. Room temperature impedance plot of $\mathrm{Li}_{1.2} \mathrm{Zr}_{1.9} \mathrm{Sr}_{0.1}\left(\mathrm{PO}_{4}\right)_{3}$ and the equivalent circuit used to interpret the data. 
Fig. 6. Temperature dependence of bulk, grain boundary and total conductivities for $\mathrm{Li}_{1.2} \mathrm{Zr}_{1.9} \mathrm{Sr}_{0.1}\left(\mathrm{PO}_{4}\right)_{3}$.

Fig. 7. Vickers hardness of $\mathrm{Li}_{1.2} \mathrm{Zr}_{1.9} \mathrm{Sr}_{0.1}\left(\mathrm{PO}_{4}\right)_{3}$ as a function of applied load.

Fig. 8. Room temperature impedance plot of $\mathrm{Li}_{/} / \mathrm{Li}_{1.2} \mathrm{Zr}_{1.9} \mathrm{Sr}_{0.1}\left(\mathrm{PO}_{4}\right)_{3} / \mathrm{Li}$ and the equivalent circuit used to interpret the data.

Fig. 9. $\mathrm{Li}-\mathrm{Li}_{1.2} \mathrm{Zr}_{1.9} \mathrm{Sr}_{0.1}\left(\mathrm{PO}_{4}\right)_{3}$ impedance as a function of time.

Fig. 10. Photograph of $\mathrm{Li}_{1.2} \mathrm{Zr}_{1.9} \mathrm{Sr}_{0.1}\left(\mathrm{PO}_{4}\right)_{3}$ after contact with metallic $\mathrm{Li}$. It was completely white prior to exposure.

Fig. 11. $\mathrm{pH}$ as a function of time for $\mathrm{Li}_{1.2} \mathrm{Zr}_{1.9} \mathrm{Sr}_{0.1}\left(\mathrm{PO}_{4}\right)_{3}, \mathrm{Li}_{6.48} \mathrm{Al}_{0.24} \mathrm{La}_{3} \mathrm{Zr}_{2} \mathrm{O}_{12}, \mathrm{Li}_{0.33} \mathrm{La}_{0.57} \mathrm{TiO}_{3}$ and $\mathrm{Li}_{1.3} \mathrm{Li}_{1.7} \mathrm{Al}_{0.3}\left(\mathrm{PO}_{4}\right)_{3}$ powders in distilled water.

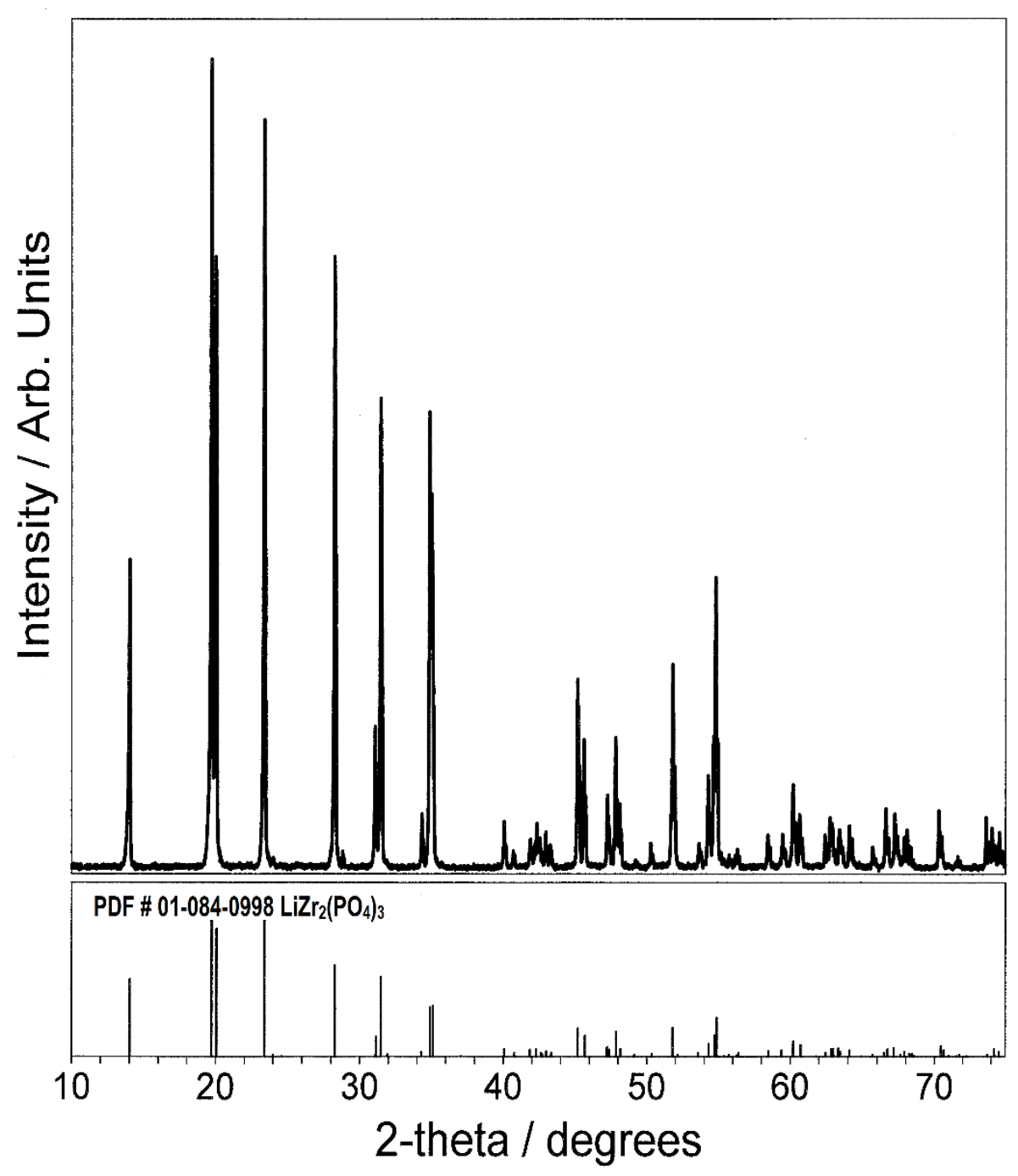


Fig. 1. X-ray diffraction pattern of hot-pressed $\mathrm{Li}_{1.2} \mathrm{Zr}_{1.9} \mathrm{Sr}_{0.1}\left(\mathrm{PO}_{4}\right)_{3}$ and reference pattern for $\mathrm{LiZr}_{2}\left(\mathrm{PO}_{4}\right)_{3}$ with the rhombohedral R $\overline{3} \mathrm{c}$ space group (PDF \#01-084-0998).

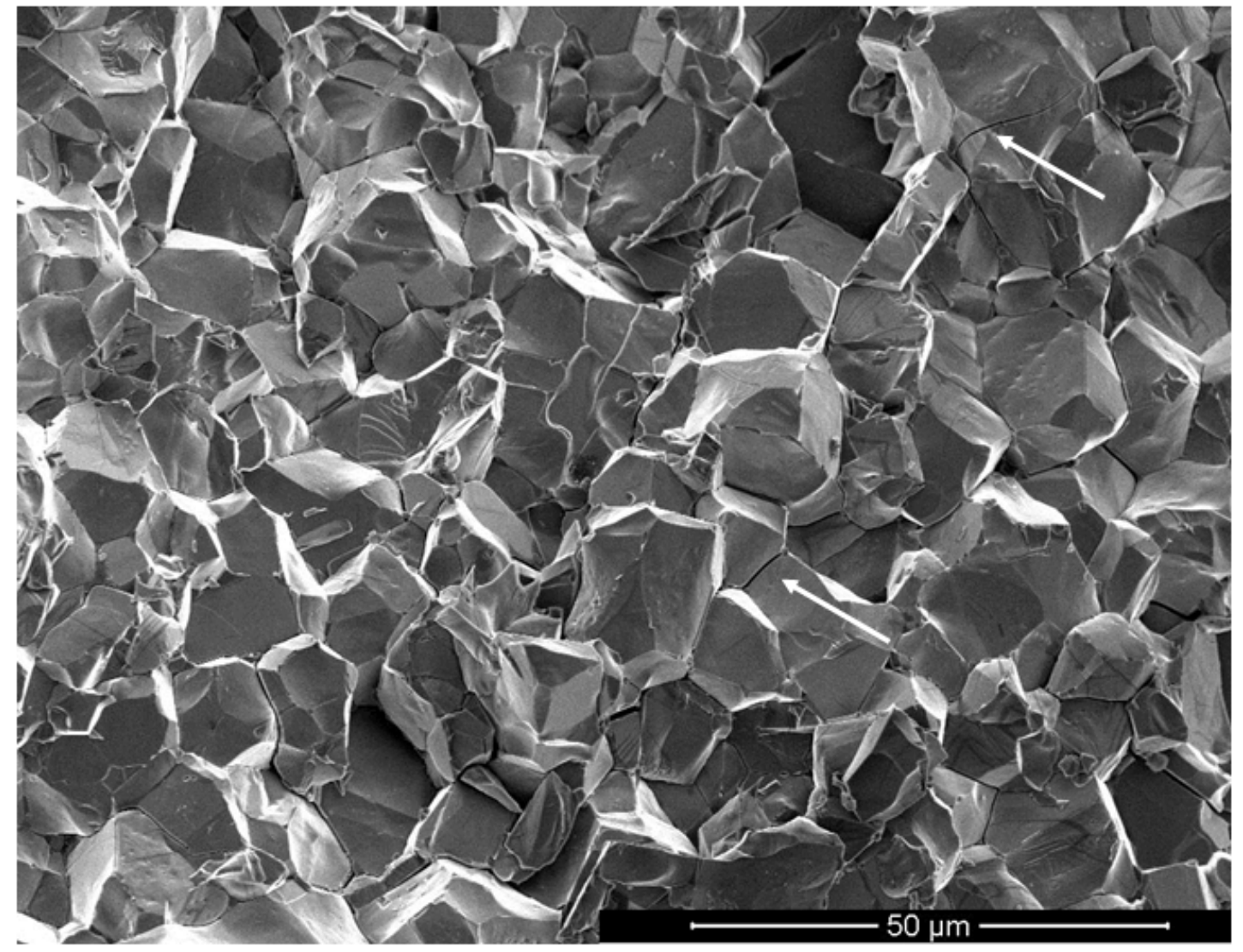


Fig. 2. Scanning electron microscopy image of $\mathrm{Li}_{1.2} \mathrm{Zr}_{1.9} \mathrm{Sr}_{0.1}\left(\mathrm{PO}_{4}\right)_{3}$ fracture surface. Arrows indicate microcracking. 


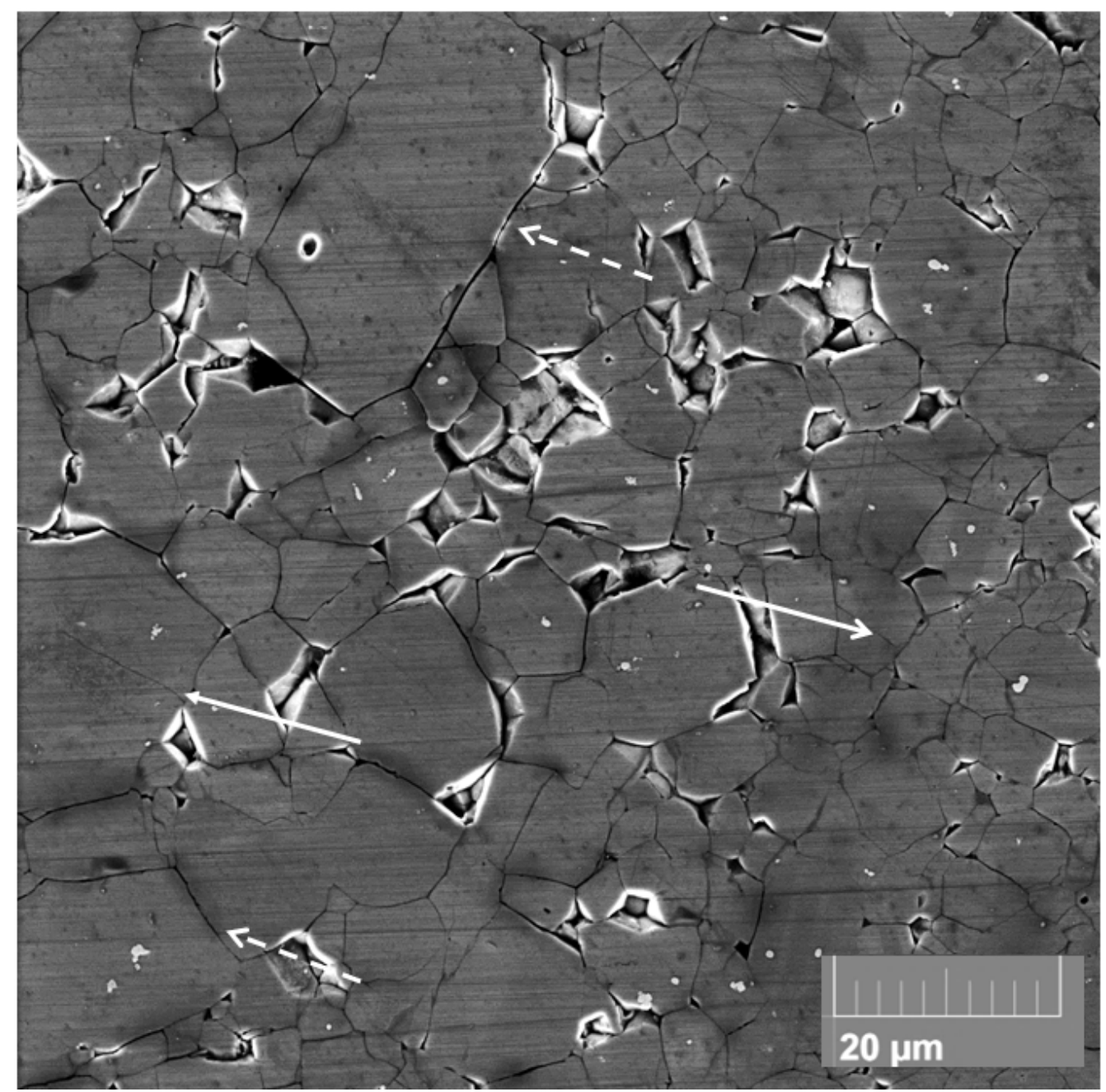

Fig. 3. Scanning electron microscopy image of $\mathrm{Li}_{1.2} \mathrm{Zr}_{1.9} \mathrm{Sr}_{0.1}\left(\mathrm{PO}_{4}\right)_{3}$ polished surface. Solid arrows indicate intragranularmicrocracks. Dotted arrows indicate intergranular microcracks 


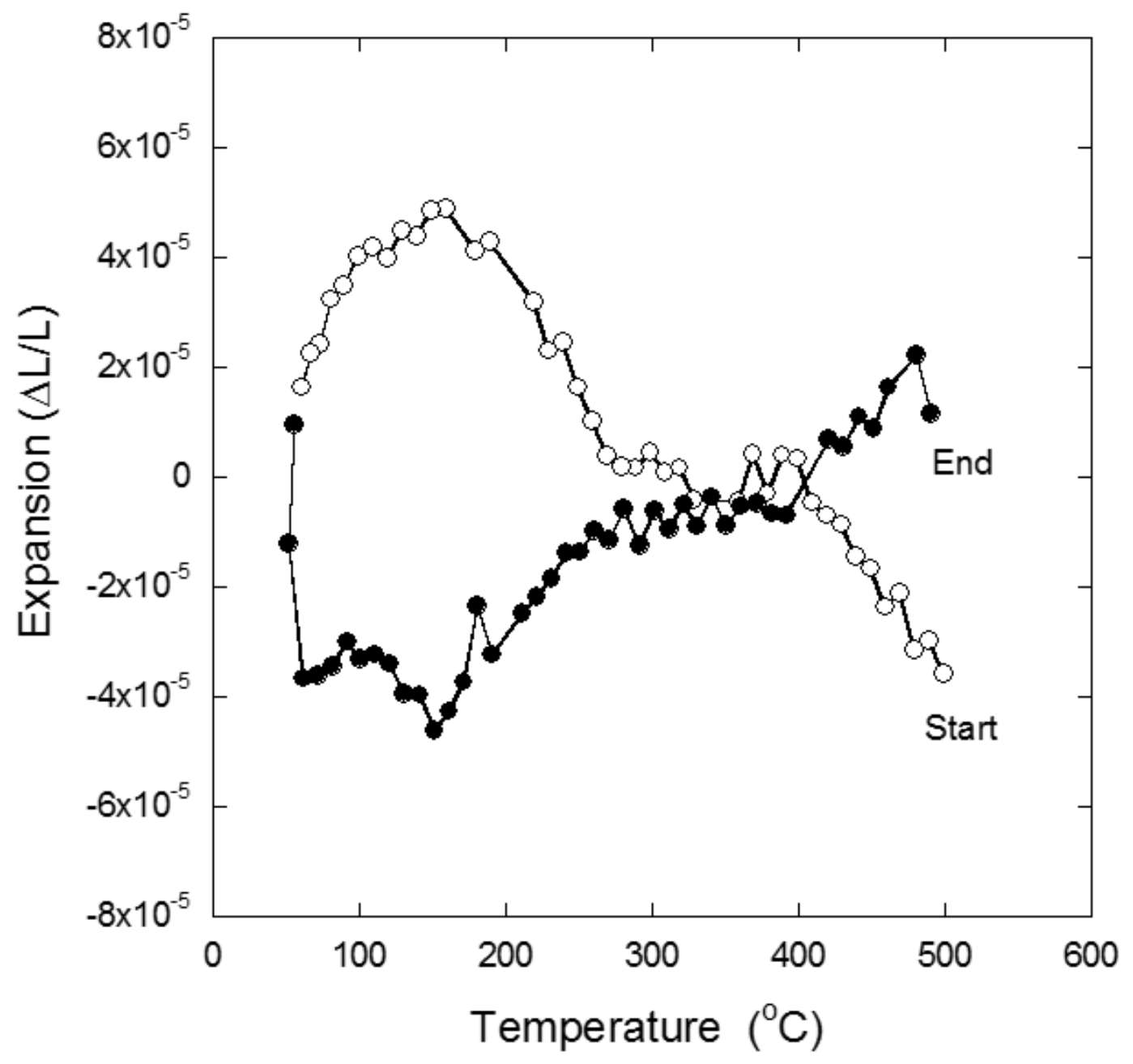

Fig. 4. Thermal expansion plot of $\mathrm{Li}_{1.2} \mathrm{Zr}_{1.9} \mathrm{Sr}_{0.1}\left(\mathrm{PO}_{4}\right)_{3}$ as a function of temperature. Open symbols represent the cooling cycle. Closed symbols represent the heating cycle. 


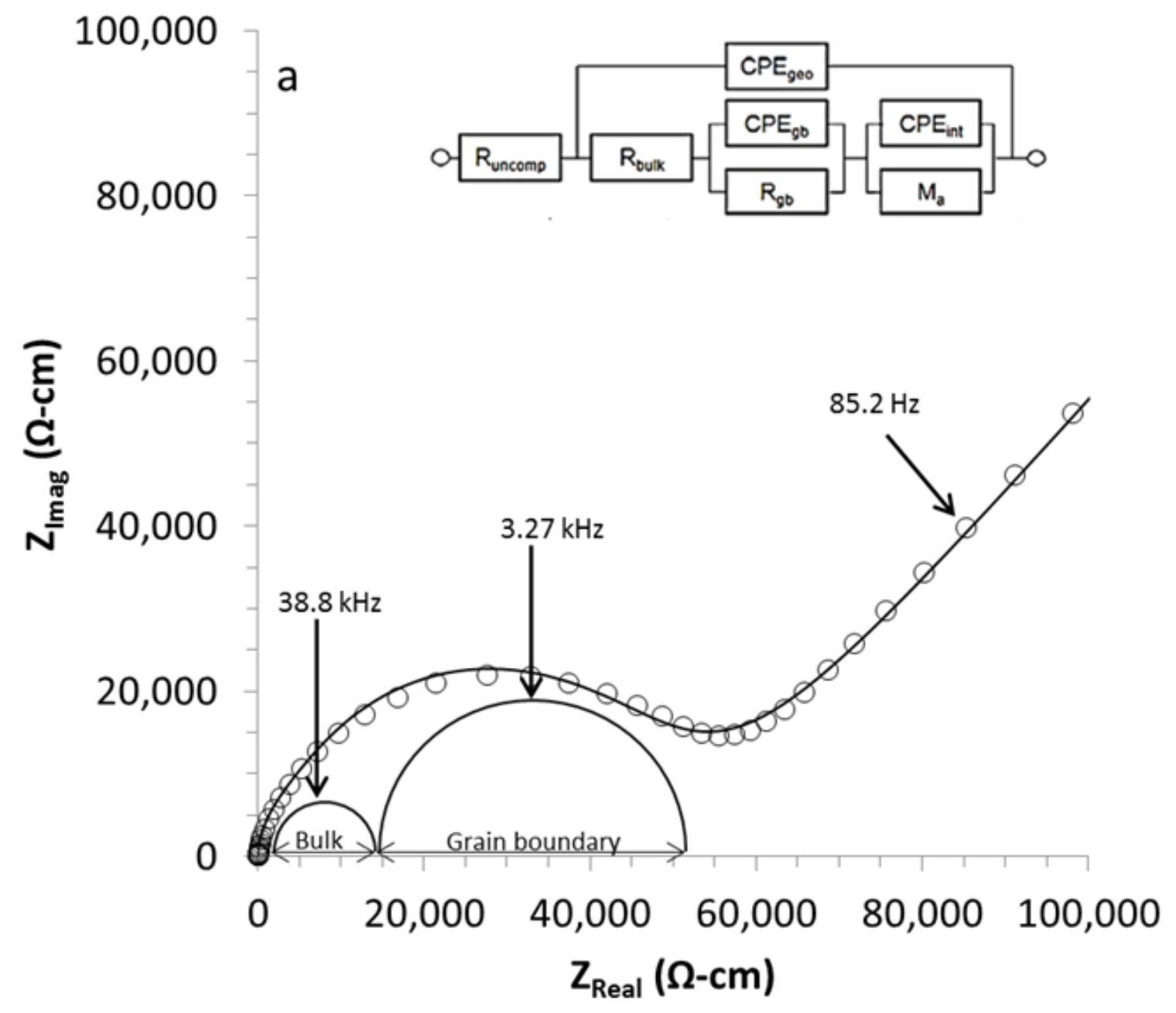

Fig. 5. Room temperature impedance plot of $\mathrm{Li}_{1.2} \mathrm{Zr}_{1.9} \mathrm{Sr}_{0.1}\left(\mathrm{PO}_{4}\right)_{3}$ and the equivalent circuit used to interpret the data. 


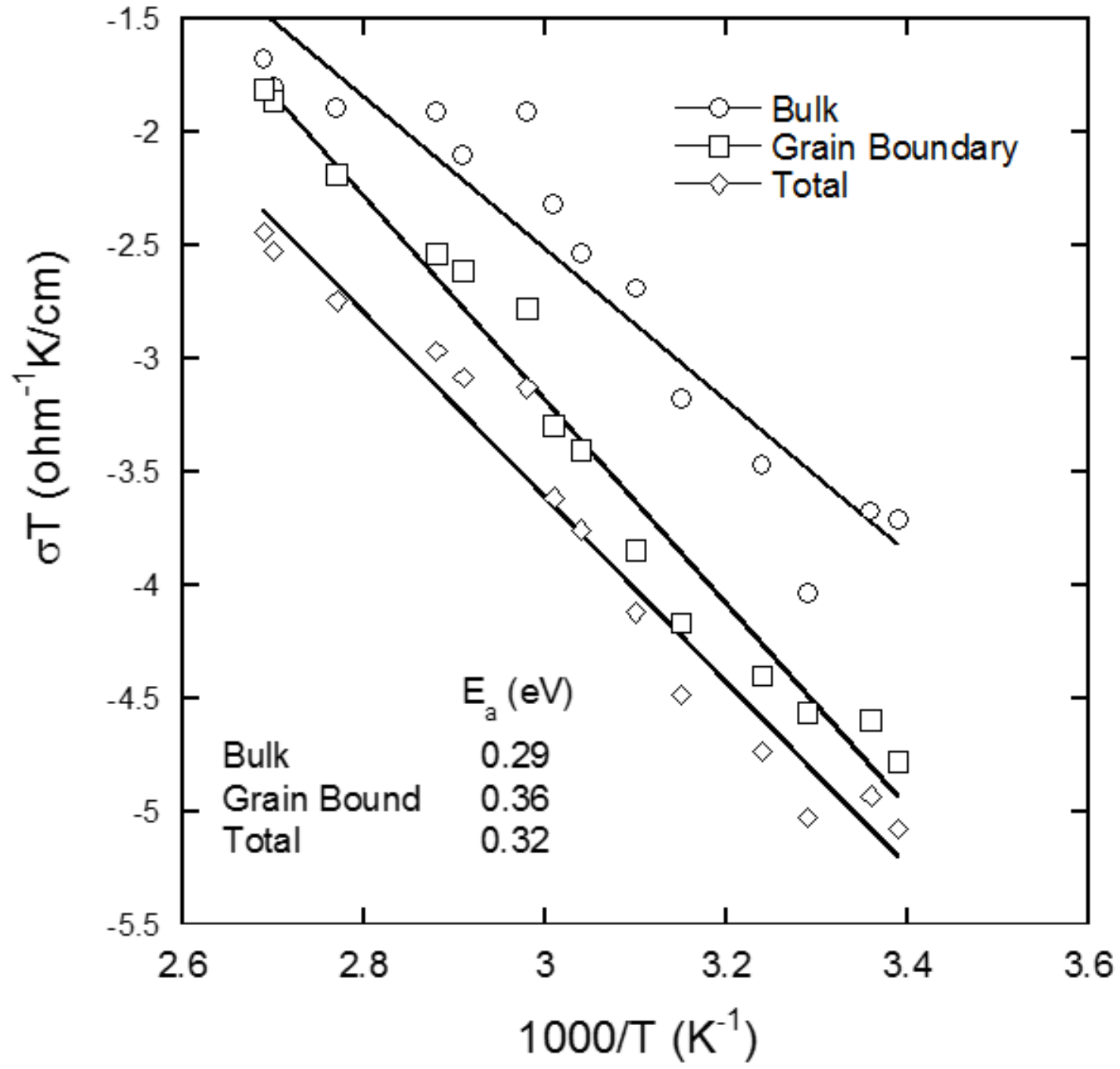

Fig. 6. Temperature dependence of bulk, grain boundary and total conductivities for $\mathrm{Li}_{1.2} \mathrm{Zr}_{1.9} \mathrm{Sr}_{0.1}\left(\mathrm{PO}_{4}\right)_{3}$. 


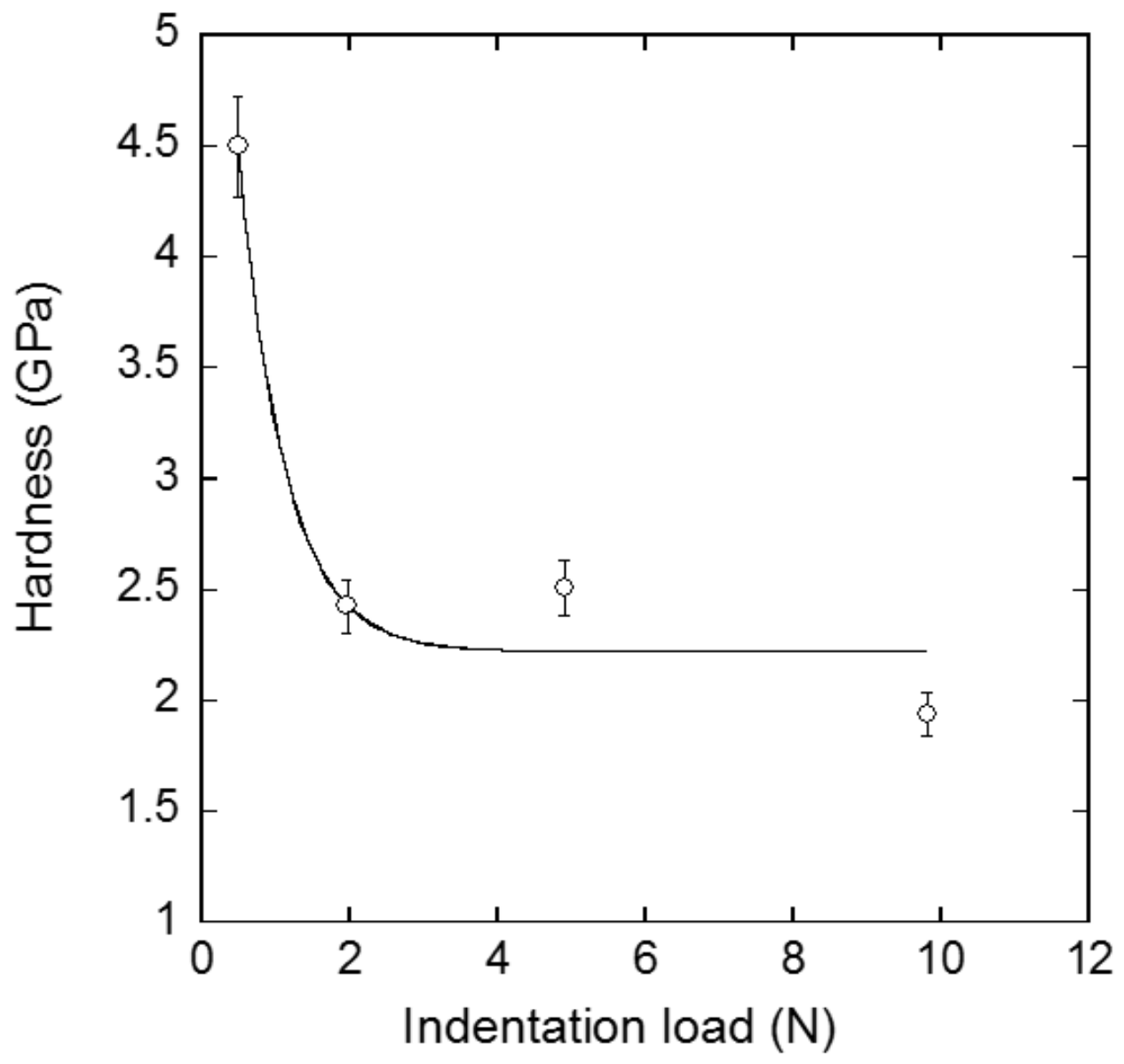

Fig. 7. Vickers hardness of $\mathrm{Li}_{1.2} \mathrm{Zr}_{1.9} \mathrm{Sr}_{0.1}\left(\mathrm{PO}_{4}\right)_{3}$ as a function of applied load. 


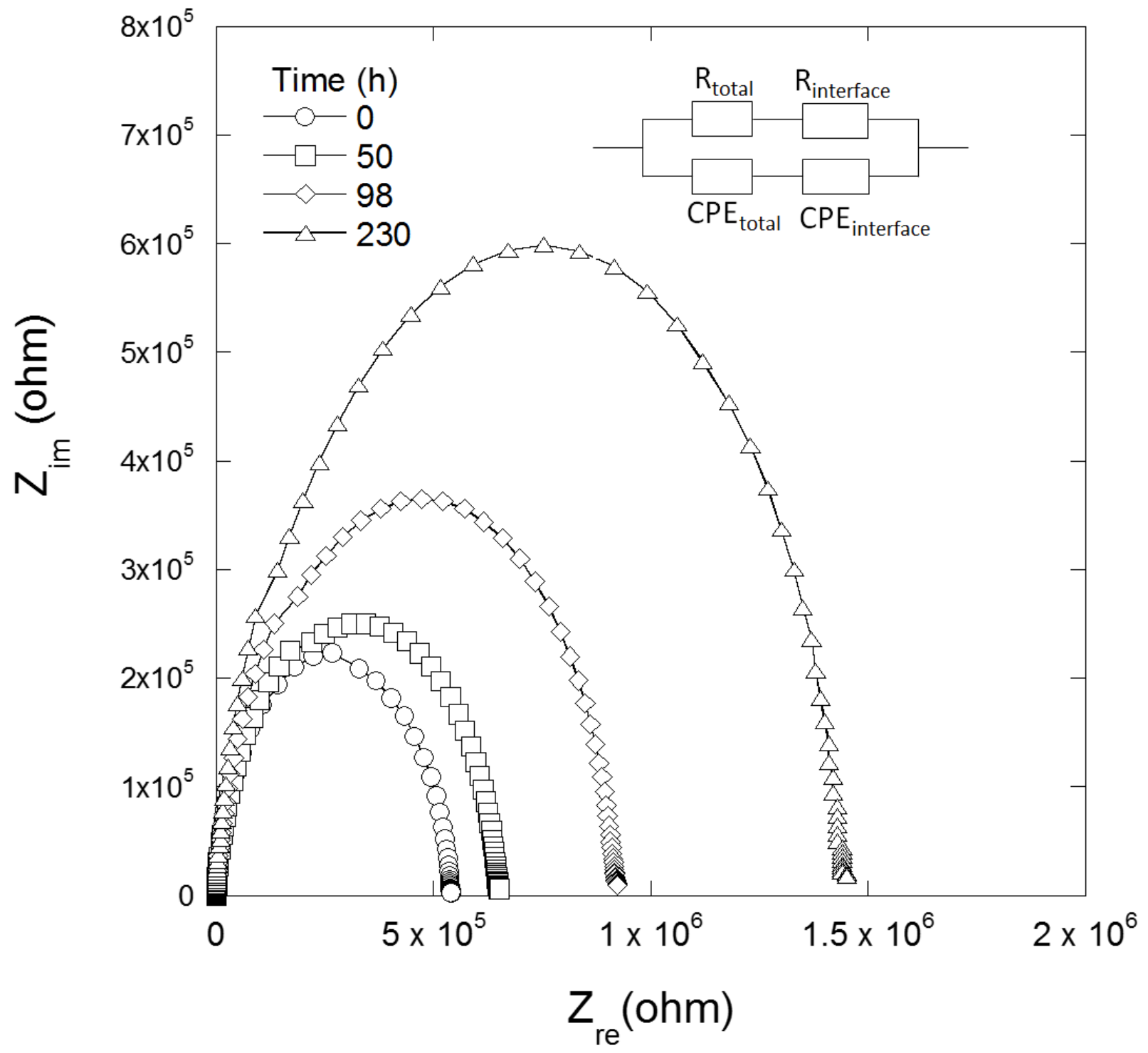

Fig. 8. Room temperature impedance plot of $\mathrm{Li} / \mathrm{Li}_{1.2} \mathrm{Zr}_{1.9} \mathrm{Sr}_{0.1}\left(\mathrm{PO}_{4}\right)_{3} / \mathrm{Li}$ and the equivalent circuit used to interpret the data. 


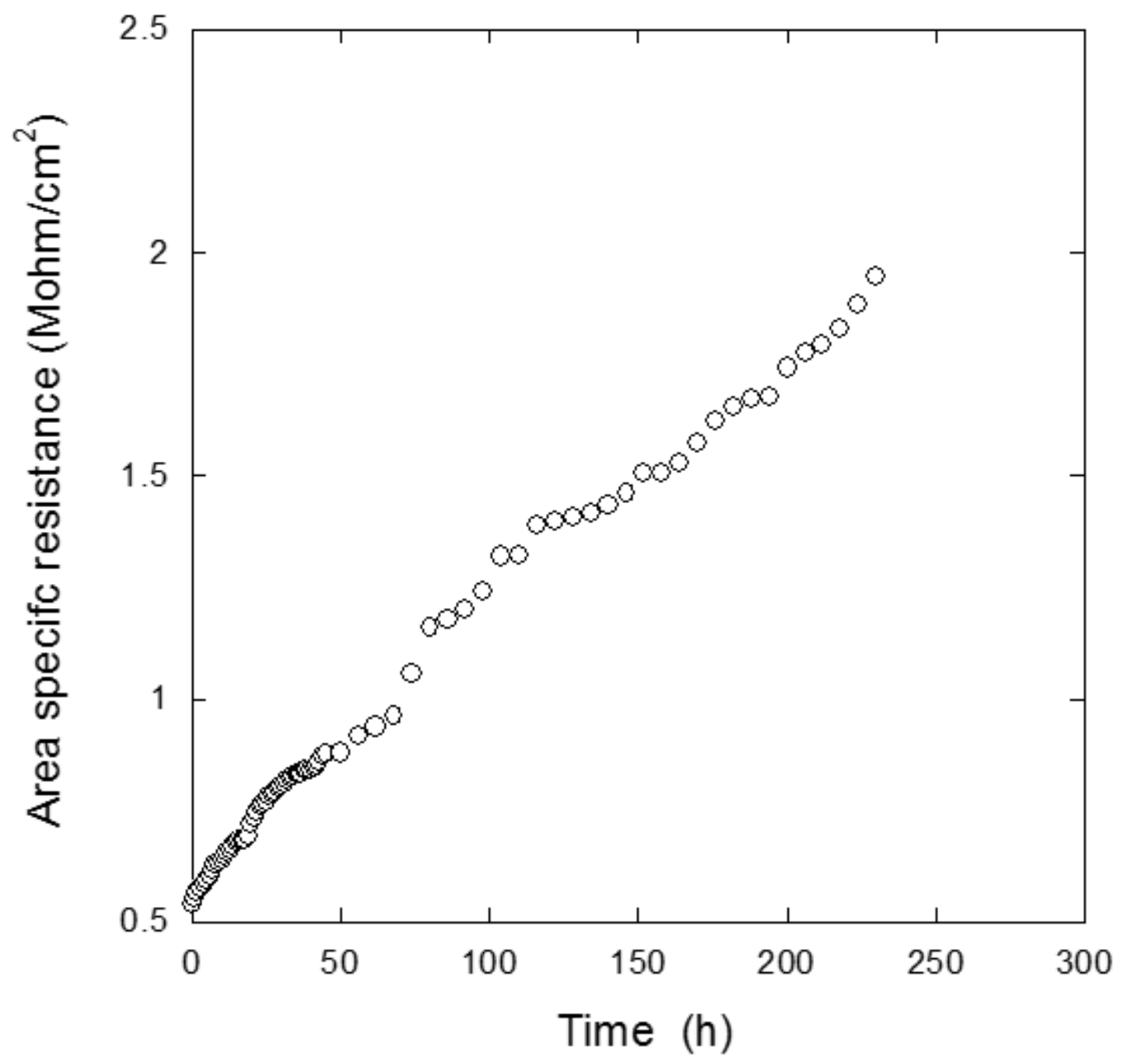

Fig. 9. $\mathrm{Li}-\mathrm{Li}_{1.2} \mathrm{Zr}_{1.9} \mathrm{Sr}_{0.1}\left(\mathrm{PO}_{4}\right)_{3}$ impedance as a function of time. 


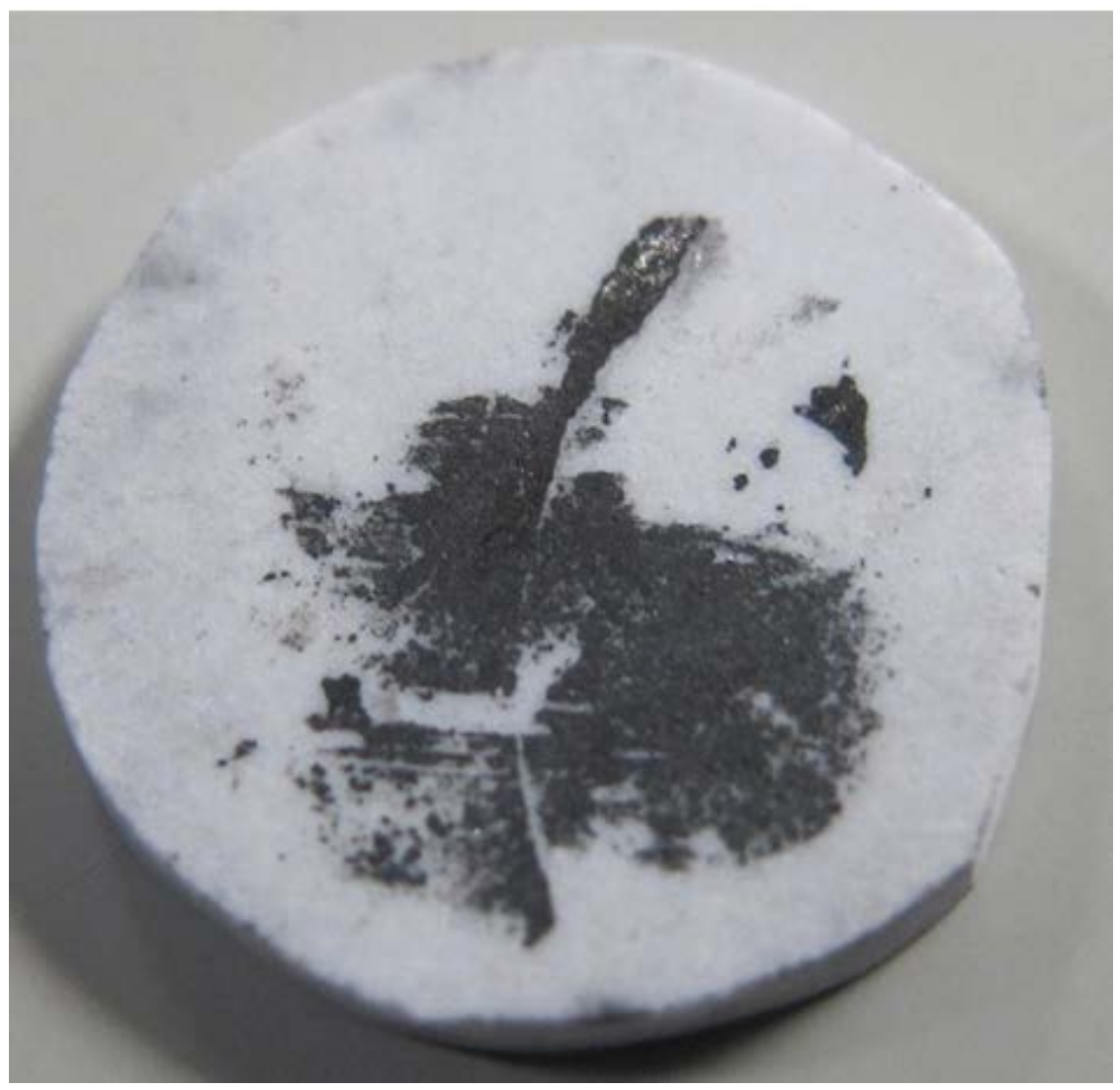

Fig. 10. Photograph of $\mathrm{Li}_{1.2} \mathrm{Zr}_{1.9} \mathrm{Sr}_{0.1}\left(\mathrm{PO}_{4}\right)_{3}$ after contact with metallic Li. It was completely white prior to exposure. 


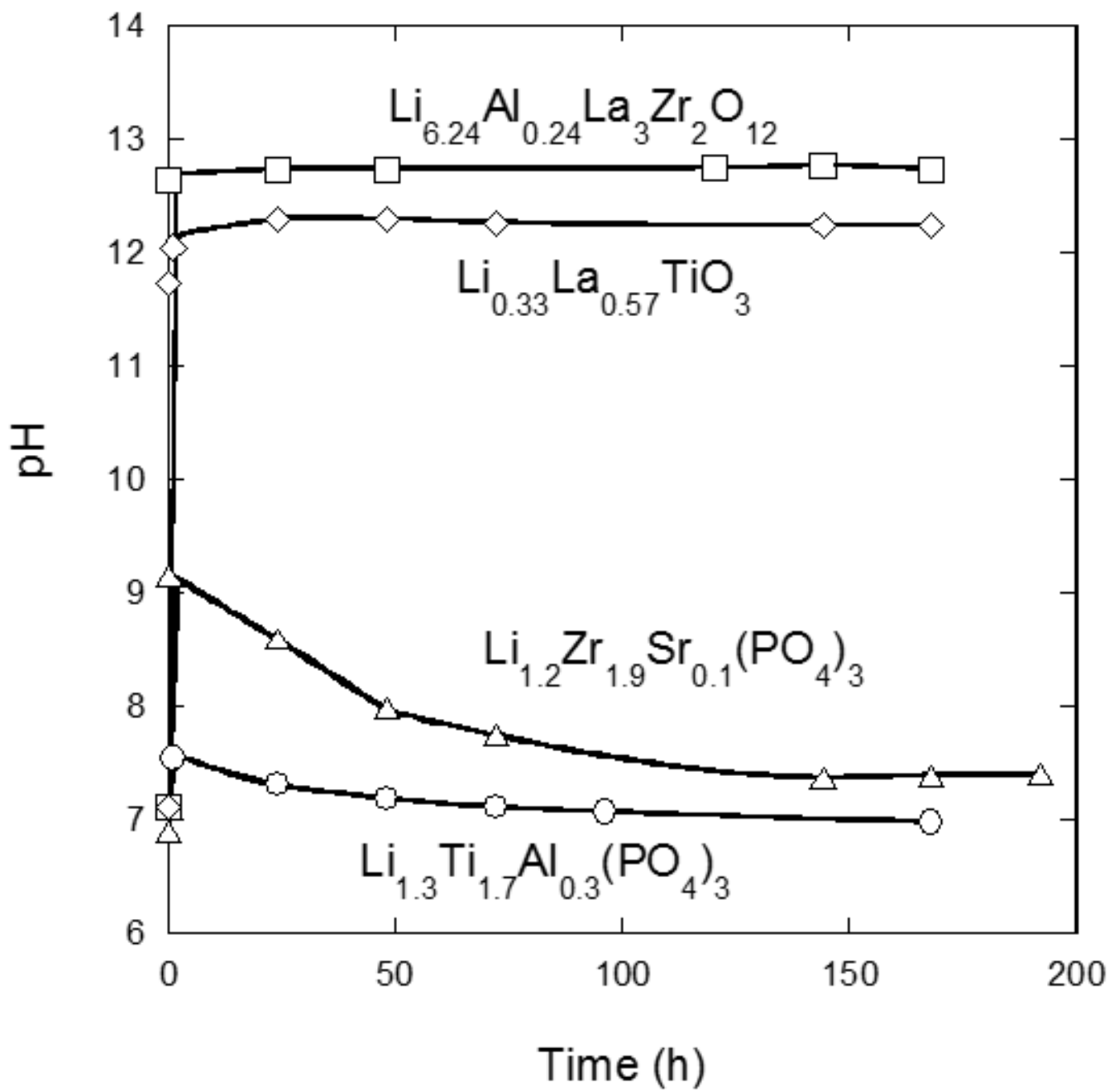

Fig. 11. $\mathrm{pH}$ as a function of time for $\mathrm{Li}_{1.2} \mathrm{Zr}_{1.9} \mathrm{Sr}_{0.1}\left(\mathrm{PO}_{4}\right)_{3}, \mathrm{Li}_{6.48} \mathrm{Al}_{0.24} \mathrm{La}_{3} \mathrm{Zr}_{2} \mathrm{O}_{12}, \mathrm{Li}_{0.33} \mathrm{La}_{0.57} \mathrm{TiO}_{3}$ and $\mathrm{Li}_{1.3} \mathrm{Li}_{1.7} \mathrm{Al}_{0.3}\left(\mathrm{PO}_{4}\right)_{3}$ powders in distilled water. 